\title{
FRACIONAMENTO DE FÓSFORO DE SOLOS INCUBADOS COM VINHAÇA
}

\author{
MARIA EMILIA MATTIAZZO PREZOTTO
}

Orientador: Dr. NADIR ALMEIDA DA GLÓRIA

\begin{abstract}
Dissertação apresentada à Escola Superior de Agricultura "Luiz de Queiroz", da Universidade de São Paulo, para obtenção do título de Mestre em Solos e Nutrição de Plantas.
\end{abstract}

\author{
PIRACICABA \\ Estado de São Paulo - Brasil \\ Fevereiro, 1979
}


Ofereço, com amor, aos meus pais

Luiz e Djanira

e a Wanderley José,

meu espôso 


\section{RECONHECIMENTOS}

Este trabalho não teria sido possỉvel sem o inestimāvel apoio:

- do Prof. Dr. Nadir Almeida da Gloria, pela orientação e principalmente pela amizade e confiança;

- dos auxiliares de laboratōrio, Francisco Carraro, Silene Loureiro Novaes, Gertrudes Claudia Barbieri, Maria Cecilia Pizzinato e Willians Gustinelli pela colaboração nas anālises;

- do Conselho Nacional de Desenvolvimento Cientifico e Tecnolögico CNPG, pelo crédito na seriedade do trabalho traduzido em subsidios durante 0 curso.

Não poderia, tambēm, deixar de agradecer

à Maria Elisabeth Ferreira de Carvalho e Luiz Carlos Verissimo, bibliotecārios da ESALQ, pelo auxîlio nas citaçōes bibliogrä́ficas;

à Sra. Margareth $P$. Wagner pela versão para 0 inglês do resumo;

à Elisa S.Peron, pelos trabalhos de datilografia e, enfim,

a todos que colaboraram para a realização desse trabalho. 


\section{INDICE}

Pägina

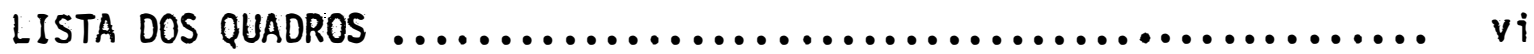

LISTA DAS FIGURAS $\ldots \ldots \ldots \ldots \ldots \ldots \ldots \ldots \ldots \ldots \ldots \ldots \ldots \ldots \ldots, \ldots \ldots \ldots$ vii

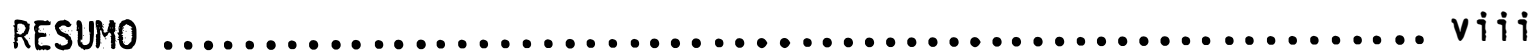

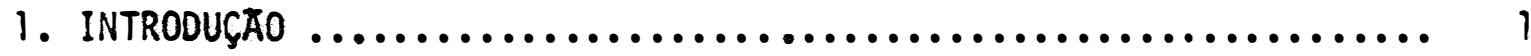

2. REVISAO DA LITERATURA $\ldots \ldots \ldots \ldots \ldots \ldots \ldots \ldots \ldots \ldots \ldots \ldots \ldots \ldots \ldots$

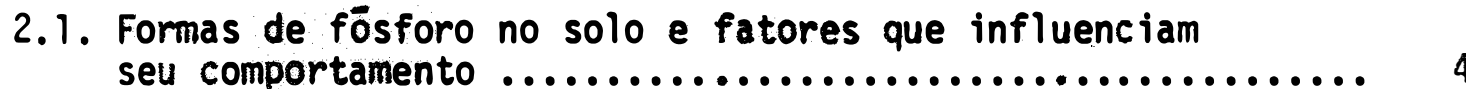

2.1.1. Efeito do $\mathrm{pH}$ no fösforo do solo ..................

2.1.2. Formas de fósforo nos solos .................. 5

2.2. Efeito da vinhaça e de outras fontes de matēria orgânica aplicadas aos solos .......................... 12

2.2.1. Efeito no $\mathrm{pH}$ do solo ......................... 13

2.2.2. Efeito na disponibilidade de fósforo do solo ...... 14

2.2.3. Efeito no poder de retenção de câtions pelo solo ........................................ 18

2.2.4. Efeito na população e atividade microbiana do solo ......................................... 19

2.3. Métodos de fracionamento para fösforo em solos .......... 21

3. MATERIAL E METODOS $\ldots \ldots \ldots \ldots \ldots \ldots \ldots \ldots \ldots \ldots \ldots \ldots \ldots \ldots, 25$

3.1. Material ..................................... 25

3.2. Montagem do experimento $\ldots \ldots \ldots \ldots \ldots \ldots \ldots \ldots \ldots \ldots \ldots, 26$

3.3. Metodos .......................................... 30 
Pāgina

4. RESULTADOS OBTIDOS E DISCUSSAO $\ldots \ldots \ldots \ldots \ldots \ldots \ldots \ldots \ldots \ldots \ldots, 36$

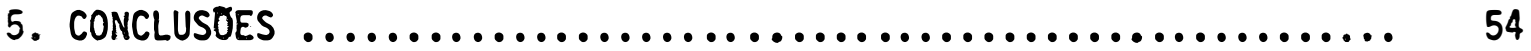

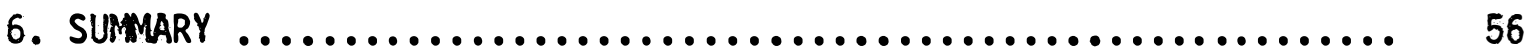

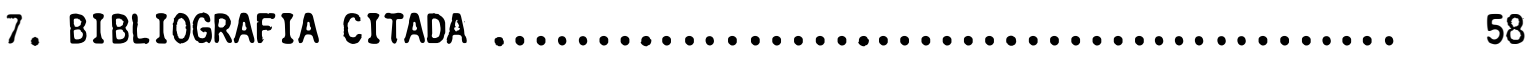

APENDICE 


\section{LISTA DOS QUADROS}

Quadro n?

Pāgina

1 Anālise química dos solos empregados ...............

2 Algumas características dos solos empregados (segundo RANZANI et alii, 1066)

3 Anālise dos fosfatos utilizados no experimento

4 Esquema da monstagem do experimento ................

5 Variação do $\mathrm{pH}$ do substrato, nos tratamentos

com Regossol, durante o transcorrer do experimento

6 Variação do $\mathrm{pH}$ do substrato nos tratamentos

com Latossol, durante o transcorrer do ex-

perimento

7 Teores de fósforo em ppm P, extraỉdos com so-

lução $0,5 \mathrm{~N}$ de $\mathrm{H}_{2} \mathrm{SO}_{4}$ nos diferentes tratamen-

tos com Regossol e nos diferentes tempos .............

8 Teores de fósforo, em ppm de $P$, extraỉdos com solução $0,05 \mathrm{~N}$ de $\mathrm{H}_{2} \mathrm{SO}_{4}$, nos diferentes trátamentos com Latossol e nos diferentes tempos .......... 
$1 \quad \mathrm{pH}$ e formas de fösforo nos tratamentos com Regossol apōs 30 dias do inīcio do experimento .............. 39

$2 \mathrm{pH}$ e formas de fósforo nos tratamentos com Regossol apōs 60 dias do inīcio do experimento ............... 40

3 pH e formas de fósforo nos tratamentos com Regossol apōs 90 dias do inīcio do experimento ............... 41

$4 \quad \mathrm{pH}$ e formas de fósforo nos tratamentos com Regossol apōs 122 dias do início do experimento .............. 42

5 pH e formas de fósforo nos tratamentos com Regossol apōs 183 dias do início do experimento ............. 43

6 pH e formas de fösforo nos tratamentos com Latossol apōs 30 dias do início do experimento ............... 44

7 pH e formas de fösforo nos tratamentos com Latossol apōs 60 dias do inicio do experimento .............. 45

8 pH e formas de fósforo nos tratamentos com Latossol apōs 91 dias do início do experimento .............. 46

9 pH e formas de fösforo nos tratamentos com Latossol apōs 122 dias do inīcio do experimento ............. 47

10 pHe formas de fósforo nos tratamentos com Latnssol após 183 dias do inîcio do experimento ............. 48 
RESUMO

O objetivo do presente trabalho è o estudo do comportamento do fösforo em solos incubados com vinhaça.

Para a montagem do experimento, foram utilizados dois diferentes tipos de solos (Regossol sērie Sertãozinho e Latossol sērie Iracema) onde, de acordo com o tratamento, foram incorporados fosfato solúvel, fosfato insolūvel, vinhaça e āgua. Periodicamente retirou-se amostras de cada tratamento nas quais foram determinados pH, fósforo solūvel em $\mathrm{H}_{2} \mathrm{SO}_{4} 0,05 \mathrm{~N}$ e as diferentes formas de fösforo de acordo com a metodologia proposta por CHANG e JACKSON (1957a).

Com os resultados obtidos pode-se concluir que:

- O fosfato solúvel tem diferentes destinos dependendo do tipo de solo onde ele $\bar{e}$ aplicado. No Regossol que $\bar{e}$ um solo com baixo teor de $\mathrm{Fe}_{2} \mathrm{O}_{3}$ livre o fósforo precipita-se preferencialmente como compostos de aluminio. No Latossol que $\bar{e}$ um solo com alto teor de $\mathrm{Fe}_{2} \mathrm{O}_{3}$ livre o fosfato aplicado é encontrado como compostos de fósforo e ferro. 
- A adição de vinhaça não modifica as transformações que ocorrem com o fosfato solūvel aplicado ao Regossol, porēm a aplicação con junta de vinhaça mais fosfato solūvel ao Latossol faz com que o nivel de fosfatos de cāicio que são as formas mais solūveis de fosfatos sejam mantidas por um tempo mais longo.

- A adição de fosfato insolūvel (fosfato natural) aos solos do experimento aumentou o nỉvel das formas de fösforo ligadas ao cālcio, o que é de se esperar devido ao fato do fosfato natural usado no experimento ser um fosfato de cālcio. Com o decorrer do tempo esse fosfato passa para as formas menos solúveis de $\mathrm{P}-\mathrm{Al}$ e $\mathrm{P}-\mathrm{Fe}$, independente do tipo de solo.

- A adição conjunta de fosfato insolūvel (fosfato natural) e vinhaça, aos solos do experimento conserva esse fosfato de cālcio adicionado por mais tempo como tal. 
1. INTRODUÇÃO

A importância do fōsforo na nutrição vegetal e animal é fato plenamente reconhecido devendo-se entretanto, ressaltar que o suprimento desse elemento encontra-se no solo.

A quantidade total de fösforo nos solos è bastante variāvel e pouco esclarece sobre a capacidade de fornecimento desse nutriente aos vegetais, uma vez que a maior parte do fósforo do solo encontra-se numa condição não assimilável pela planta, principalmente nos solos tropicais que tem alta capacidade de fixação de fosfato (CATANI, 1969). Desse fato decorre a necessidade da adição de fertilizantes fosfatados aos solos e, como consequência, o consumo de adubos fosfatados pela agricultura brasileira, vem aumentando a cada ano. Segundo boletim informativo da ANDA (1978) em 1977 foram consumidas 1.533 .502 toneladas de $P_{2} O_{5}$ na forma de di ferentes fertilizantes fosfatados, sendo que deste total $31 \% \bar{e}$ de produto importado. Todavia, é preciso considerar que, no caso da produção de $\mathrm{P}_{2} \mathrm{O}_{5}$, O Brasil possue em exploração duas reservas de rocha fosfática; em uma delas, toda a produção de concentrados obtido è empregado no processo 
de solubilização; na outra, parte do minério ē vendido para a aplicação di reta ao solo (menos de $7 \%$ do total do consumo de fertilizantes fosfatados) e parte é encaminhada para o fabrico de fertilizantes fosfatados solúveis, sendo que essa solubilização faz uso de matēria prima importada (GONÇALVES, 1977, ANDA, 1978).

A importância de tais dados para a economia brasileira e ressaltada quando se considera que nossas reservas de fosfatos naturais, poderian perfeitamente atender nossa demanda se não houvesse 0 problema da baixa solubilidade desses materiais quando adicionados ao solo.

A influência benēfica da matēria orgânica do solo (natural ou incorporada) sobre a solubilização de fosfatos tem sido registrada pela literatura (STANFORD e PIERRE, 1953; BEAR, 1964; MALAVOLTA, 1967; BUCKMAN e BRADY, 1968), podendo-se desta maneira supor que, havendo uma fonte disponivel de matéria orgânica terỉamos um processo para aumentar a disponibi lidade de fosfato.

As destilarias de ālcool ou aguardente produzem como principal residuo a vinhaça que tem sido uma constante preocupação dos örgãos responsāveis pelo controle da poluição. Tendo em vista o programa governa mental denominado Plano Nacional do Alcool, quando a produção de $8.000 .000 \mathrm{~m}^{3}$ de àlcool for atingida, serão produzidos tambēm $104.000 .000 \mathrm{~m}^{3}$ de vinhaça 0 que equivale à demanda bioquīmica de oxigênio (BOD) gerada por uma população de 77.037.036 habitantes (GLORIA, 1977a) evidenciando como è proibitiva a idéia do despejo desses resỉduos nos cursos dāgua. 
Dessa maneira aliou-se os dois problemas acima descritos e, usando-se como fonte de matéria orgānica a vinhaça procurou-se verificar seu efeito sobre o fósforo do solo (na tural ou incorporado, na forma solúvel ou insolúvel).

$$
\text { GLORIA e MATTIAZZO, (1976a); GLORIA e MATTIAZZO, (1976b), ve }
$$
rificaram que em condições de laboratōrio, em experimentos tipo Neubauer, não houve efeito que evidenciasse o aumento da disponibilidade do fósforo em solos onde foi adicionada vinhaça. Uma vez que tais resultados foram opostos ao que se poderia esperar face aquilo que consta na literatura à respeito dos efeitos da matēria orgânica sobre a disponibilidade de fosfato do solo, pretendeu-se contribuir para o esclarecimento das transformações que ocorrem nas formas de fosfato do solo, apōs a aplicação de vinhaça, realizando este trabalho. 


\section{REVISAO DA LITERATURA}

Para facilidade de apresentação a revisão da literatura ē apresentada abordando os aspectos principais do assunto, isoladamente.

\subsection{Formas de fösforo no solo e fatores que influenciam seu comporta-} mento

\subsubsection{Efeito do pH no fósforo do solo}

o fösforo inorgânico ocorre nos solos como ànion dos qua is o principal è o ânion dihidrogênio fosfato $\left(\mathrm{H}_{2} \mathrm{PO}_{4}^{-}\right)$. 0 citado ânion é derivado do àcido fosfórico, um àcido triprōtico cujas reaçōes e constantes de ionização são representadas como se segue (PRATT, 1966).

$$
\begin{array}{ll}
\mathrm{H}_{3} \mathrm{PO}_{4} \rightarrow \mathrm{H}^{+}+\mathrm{H}_{2} \mathrm{PO}_{4}^{-} & \mathrm{Kac}_{1}=7,6.10^{-3} \\
\mathrm{H}_{2} \mathrm{PO}_{4}^{-} \rightarrow \mathrm{H}^{+}+\mathrm{HPO}_{4}^{2-} & \mathrm{Kac}_{2}=6,3.10^{-8} \\
\mathrm{HPO}_{4}^{2-} \rightarrow \mathrm{H}^{+}+\mathrm{PO}_{4}^{3-} & \mathrm{Kac}_{3}=4,8.10^{-13}
\end{array}
$$


Como se pode verificar apenas a primeira ionização do ācido fosförico ocorre com relativa facilidade e portanto, numa solução aquosa do citado ácido a forma predominante dependerā do pH do meio. Em valores de $\mathrm{pH}$ inferiores a 2,1 a forma dominante de fósforo solūvel ē $\mathrm{H}_{3} \mathrm{PO}_{4}$; em valores de $\mathrm{pH}$ superiores a 12,3 a forma $\mathrm{PO}_{4}^{3-}$ è dominante; $\mathrm{HPO}_{4}^{2-}$ é dominante no intervalo de $\mathrm{pH}$ de 7,2 a 12,3. Portanto na faixa de $\mathrm{pH}$ da maio ria dos nossos solos (4 a 7) O que predominam são os ions $\mathrm{H}_{2} \mathrm{PO}_{4}^{-}$e $\mathrm{HPO}_{4}^{2-}$ sendo que as plantas absorvem preferencialmente os ions $\mathrm{H}_{2} \mathrm{PO}_{4}^{-}$(PRATT, 1966; TISDALE e NELSON, 1966; MALAVOLTA, 1976; GLORIA, 1977b).

Tudo o que foi visto sobre pH e formas de fósforo pressupõe a ausência de ions ferro, aluminio e cāicio, uma vez que em função do pH e da concentração dos citados ĩons presentes no solo poderā haver formação de compostos pouco solūveis de fósforo (PRATT, 1966; TISDALE e NELSON, 1966; GLORIA, 1977b).

Com relação à solubilidade dos compostos de fösforo pode-se dizer que a exceção dos fosfatos de metais alcalinos e fosfatos diācidos de metais alcalino terrosos, todos os demais fosfatos são insolūveis(PRATT, 1966).

2.1.2. Formas de fösforo nos solos

A ocorrência de fósforo no solo pode ser resumida da seguinte maneira: 
- fósforo inorgânico: incluindo o fósforo do material inorgânico de origem, fósforo de baixa disponibilidade pela fixação do solo e o fósforo presente na solução do solo.

- fósforo orgânico do solo: que inclue todas as formas orgânicas de fósforo inclusive a fração constituinte do "esqueleto" dos microrganismos.

2.1.2.1. Fōsforo inorgânico:

A principal caracterīstica dos compostos de fósforo è a bai xa solubilidade (HSU e JACKSON, 1960; BEAR, 1964; PRATT, 1966; PHILLIPS e WEBB, 1973) e isso explica o fato do fósforo predominar no solo na forma inorgânica insolüvel e, nestas condições, pode aparecer sob forma de diferentes compostos sendo que, para solos ácidos, como è o caso de solos tropicais, estão em evidēncia as seguintes (MALAVOLTA, 1.976).

$\begin{array}{ll}\frac{\text { denominação }}{\text { fluorapatita }} & \frac{\text { förmula }}{\mathrm{Ca}}{ }_{10}\left(\mathrm{PO}_{4}\right)_{6} \mathrm{~F}_{2} \\ \text { cloroapatita } & \mathrm{Ca}_{10}\left(\mathrm{PO}_{4}\right)_{6} \mathrm{Cl}_{2} \\ \text { hidroxiapatita } & \mathrm{Ca}_{10}\left(\mathrm{PO}_{4}\right)_{6}(\mathrm{OH})_{2} \\ \text { oxiapatita } & \mathrm{Ca}_{10}\left(\mathrm{PO}_{4}\right)_{6}{ }^{\mathrm{O}} \\ \text { strengita } & \mathrm{Fe}(\mathrm{OH})_{2} \mathrm{H}_{2} \mathrm{PO}_{4} \\ \text { variscita } & \mathrm{Al}(\mathrm{OH})_{2} \mathrm{H}_{2} \mathrm{PO}_{4}\end{array}$


denominação.

vivianita

taranakitas

fosfato tricālcico

fosfato bicālcico

fosfato monocālcico förmula

$\mathrm{Fe}_{3}\left(\mathrm{PO}_{4}\right)_{2} \mathrm{BH}_{2} \mathrm{O}$

$\mathrm{M}_{3} \mathrm{Al}_{5} \mathrm{H}_{6}\left(\mathrm{PO}_{4}\right)_{3}{ }^{18 \mathrm{H}_{2} \mathrm{O}}$

$M=\mathrm{NH}_{4}^{+}$ou $\mathrm{K}^{+}$

$\mathrm{Ca}_{3}\left(\mathrm{PO}_{4}\right)_{2}$

$\mathrm{CaHPO}_{4}$

$\mathrm{Ca}\left(\mathrm{H}_{2} \mathrm{PO}_{4}\right)_{2}$

Os fosfatos de călcio são as formas mais solūveis dentre as formas inorgânicas de fósforo e tendem a reverter às formas menos solūveis de fosfatos de ferro e aluminio em solos ácidos, e este fato, somado à sua maior disponibilidade às plantas mantēm baixo o nỉvel de fosfatos de cā cio nestes solos. Dessa maneira fosfatos de ferro que são as formas menos solūveis de fösforo tendem a se acumular nos solos äcidos às custas das formas mais solūveis de fósforo e que são respectivamente fosfatos de cālcio e fosfatos de alumínio (MALAVOLTA e PELLEGRINO, 1954; CHANG e JACKSON, 1957b; CHANG e JACKSON, 1958; CATANI e PELLEGRINO, 1960; HSU e JACKSON, 1960; YUAN et alii, 1960; CHANG e CHU, 1961; GRACIO e LIMA, 1962; CHANG e JUO, 1963; VOLK e MCLEAN, 1963; CATANI e GLORIA, 1964; CATANI e BATAGLIA, 1968; CATANI, 1969; JORGE e VALADARES, 1969; SHERMAN, 1971; FERREIRA, 1973; PASQUAL, 1973; BAHIA Fo., 1974; CAVALCANTI, 1974; ENWEZOR, 1977). 
A partir desse fato tem sido bastante estudadas as reações do ion fosfato que podem ocasionar a chamada "fixação do ànion", isto $\bar{e}$, a passagem do fosfato de formas solūveis para formas insolūveis de fosfato. As atuais evidências (CHANG e CHU, 1961; HSU, 1964; HSU, 1965; PRATT, 1966; TISDALE e NELSON, 1966; BITTENCOURT E ZAMBELLO, 1973; BITTENCOURT e MONTANHEIRO, 1975) levam a admitir que tal fenōmeno è devido a um processo em duas etapas: primeiro uma adsorção tîpica e posteriormente devido à maior proximidade entre os ions e maior concentração, uma reação de fixação, através da formação de compostos pouco solüveis de fósforo.

Embora a fração de fósforo que estā ligada ao ferro e aluminnio, tenha a condição de mais baixa solubilidade e portanto pouca disponibilidade para os vegetais deve ser salientado que o fósforo em tais condições não é totalmente indisponĩvel para as plantas de forma que um solo com elevado teor desses fosfatos apresenta um potencial de fornecimento do elemento que não pode ser desprezado principalmente quando se considera 0 ciclo vegetativo da planta e o tempo decorrido desde que o material fosfático é adicionado ao solo (PINTO, 1974; BITTENCOURT e GOMES, 1975; BITTENCOURT et alii, 1977).

Os fosfatos recém precipitados como fosfatos de ferro, fosfatos de aluminio e fosfatos de cāicio são amorfos e nessa condição eles podem ser absorvidos pelas plantas, porém o envelhecimento desses fosfatos provocarā a sua cristalização e nestas condições sua disponibilidade ē pra ticamente nula (SHAPIRO, 1958; LAVERTY e MCLEAN, 1961; BITTENCOURT e MONTANHEIRO, 1975). 
Alguns autores, incluem tambēm na fração inorgānica de fosfato a chamada fração oclusa, constituâda principalmente de fosfatos de ferro e aluminio presos (oclusos) em concreções de óxidos hidratados de ferro, cujo conteúdo depende, em qualquer tipo de solo, do pH, da quantidade de óxidos hidratados de ferro e fosfato presentes e do tempo de reação (idade do solo) (CHANG e JACKSON, 1957a). Desde que o processo de oclusão è demorado, os solos mais velhos e mais intemperizados tendem a conter um nivel mais alto de formas oclusas de fósforo. Os solos com baixo conteüdo de fösforo ocluso, de acordo com CHANG e JACKSON (1958), são invariavelmente areias quartzosas com praticamente nenhum öxido de ferro. Esse fosfato ocluso $\bar{e}$ de pouca ou nenhuma utilidade para as plantas (STREL'CHENKO, 1973).

2.1.2.2. Fösforo orgânico:

0 conteūdo de fósforo orgānico em solos è bastante variāvel podendo estar situado numa faixa que vai desde 1 até $90 \%$ do fósforo total (BREMNER, 1956; ENWEZOR, 1966; GREB e OLSEN, 1967; BORNEHISZA, 1966; BORNEMISZA e IGUE, 1967; BORNEMISZA et alii, 1967; BUCKMAN e BRADY, 1968; JOP GE e VALADARES, 1969; ENWEZOR, 1977).

o fösforo orgânico do solo aparece sob três formas principais (FARES et alii, 1974; MALAVOLTA, 1976):

- àcidos nucleicos e nucleoproteinas, compreendendo de 2 até $10 \%$ do fósforo orgânico total e podem liberar seu fosfato pela ação de microrganismos. 
- fosfolipỉdeos - São triglicerídeos do tipo da gordura no qual os grupos hidroxilos do glicerol estão esterificados por compostos contendo fösforo. Segundo MALAVOLTA (1976) esses compostos correspondem a cerca de $2 \%$ do fósforo orgânico total, todavia FARES et alii (1974) dizem que esses compostos podem atingir atē $50 \%$ do fösforo orgânico total.

- àcido fítico e seus derivados - o àcido fîtico è um hexafosfato de inositol que tem os 12 hidrogênios substituiveis e capazes de formar sais sendo que os sais de cālcio e magnésio são insolúveis. Esses compostos podem ser hidrolizados por microrganismos no solo, liberando fos fatos que podem ser disponiveis às plantas (HANCE e ANDERSON, 1963 citado por FARES et alii, 1974).

Desde que as plantas não absorvem fósforo orgânico, ou absorvem pouco, (PRATT, 1966; TISDALE e NELSON, 1966; VAN DIEST, 1968a) essa forma de fösforo sō serā benēfica para as plantas depois de sua passagem para formas minerais. Essa mineralização, depende de um grande número de fatores que podem ser reunidos como se segue (THOMPSON et alii,1954; BIRCH, 1961; HALSTEAD, 1963; HANNAPEL et alii, 1964; BORNEMISZA, 1966; ENWEZOR, 1966; VAN DIEST, 1968):

- Conteúdo de umidade do solo

- Temperatura

- Aeração

- $\mathrm{pH}$

- Conteúdo de fósforo do substrato

- Fertilizantes 
A grande maioria dos trabalhos realizados sobre fösforo orgânico no solo, observa que seu destino permanece desconhecido. Somandose a isso a existência de numerosas formas biolōgicas de fósforo orgāni co no solo e especialmente a presença de frações de fósforo não identificadas, resulta no desenvolvimento de numerosas técnicas de extração e anālise sendo que o mētodo de SAUNDERS e WILLIANS (1955), tambēm conhecido como método de calcinação è o mais empregado por sua simplicidade e facilidade, entretanto, assim como os demais sofre restriçōes quanto a sua precisão, restrições estas que de acordo com IPINMIDUM (1973) e FARES et alii (1974) são as seguintes:

- 0 fósforo orgânico pode sofrer hidrōlise durante a extração àcida do solo não calcinado.

- Aumento da solubilidade do fósforo inorgānico pela calcinação.

- Remoção incompleta pelo extrator, do ortofosfato libertado na calcinação.

- Degradação incompleta dos fosfatos orgânicos calcinados.

Essas restriçōes são todas no sentido de subestimar os valores obtidos na anālise do fósforo orgànico. 
2.2. Efeito da vinhaça e de outras fontes de matéria orgânica aplicadas. aos solos

ALMEIDA (1952), PONTES (1959), GLORIA et alii (1972), GLORIA et alii, (1973), ARAUJ0 et alii (1976), RODELLA e FERRARI (1977) realizaram estudos acerca da composição da vinhaça e, dos dados obtidos, notase que, independentemente do tipo de matēria prima que the deu origem ela pode ser definida como um resỉduo liqquido orgânico.

GLORIA (1976) num estudo acerca do emprego da vinhaça para fertilização apresenta a composição mēdia de diferentes tipos de vinhaça a saber:

\begin{tabular}{|c|c|c|c|c|}
\hline \multirow{2}{*}{$\mathrm{kg} / \mathrm{m}^{3}$} & \multicolumn{4}{|c|}{ Tipo de vinhaça } \\
\hline & $\begin{array}{l}\text { Mosto de } \\
\text { melaço }\end{array}$ & $\begin{array}{l}\text { Mosto } \\
\text { misto }\end{array}$ & $\begin{array}{l}\text { Mosto de } \\
\text { caldo }\end{array}$ & $\begin{array}{l}\text { Mosto de } \\
\text { mandioca }\end{array}$ \\
\hline Carbono (C) & 19,2 & 11,5 & 5,9 & 10,2 \\
\hline Nitrogēnio (N) & 1,2 & 0,7 & 0,3 & 0,5 \\
\hline Fösforo $\left(\mathrm{P}_{2} \mathrm{O}_{5}\right)$ & 0,2 & 0,2 & 0,2 & 0,1 \\
\hline Potāssio $\left(K_{2} 0\right)$ & 7,8 & 4,6 & 1,2 & 4,7 \\
\hline Cälcio (CaO) & 3,6 & 1,7 & 0,7 & 1,3 \\
\hline Magnés io $(\mathrm{MgO})$ & 1,0 & 0,7 & 0,2 & 0,7 \\
\hline Enxofre $\left(\mathrm{SO}_{4}^{2-}\right)$ & 6,4 & 3,7 & 0,6 & 3,2 \\
\hline Matēria orgânica & 63,4 & 38,0 & 19,5 & 32,9 \\
\hline Relação C:N & 16,0 & 16,4 & 19,7 & 20,4 \\
\hline $\mathrm{pH}$ & 4,9 & 4,6 & 4,3 & - \\
\hline
\end{tabular}


Por estes dados pode-se observar que a vinhaça alēm do alto teor de matéria orgānica apresenta um conteúdo relativamente elevado de certos ions dos quais se destacam, potässio, sulfato e cálcio respectivamente.

Portanto, a adição de vinhaça ao solo tendo em vista a sua composição, corresponde em primeiro lugar a uma fertilização orgânica, devendo ser esperados todos os efeitos que lhe são atribuidos e que podem ser reunidos como se segue:

\subsubsection{Efeito no $\mathrm{pH}$ do solo}

De acordo com TISDALE e NELSON (1966), MALAVOLTA (1967), BUCKMAN e BRADY (1968), o processo de decomposição de materiais orgânicos adicionados aos solos envolvem a liberaçãa de ácidos orgânicos e inorgânicos que seriam responsāveis pelo desenvolvimento de condições ācidas nesses solos.

EIRA e CARVALHO (1970) estudando as variações de pH durante a decomposição de diversas fontes de matéria orgânica (composto, palha de cana, torta de algodão e glucose), por microrganismos do solo observaram que com o decorrer do tempo havia elevação do pH do solo e, das fontes de matéria orgânica estudadas, apenas a glucose causava decréscimo no pH.

Esse mesmo efeito foi observado por GLORIA et alii (1976), GLORIA e MATTIAZZO (1976), usando como fonte de matéria orgânica torta de mamona e resíduos de usinas de açūcar e destilarias. 
ALMEIDA et alii (1950), ALMEIDA et alij (1951) realizaram estudos acerca do efeito da adição de vinhaça no pH do solo e surpreenderam-se com 0 fato de haver elevação no pH do mesmo, apesar da acidez da ví nhaça. Resultados semelhantes foram obtidos por GLÖRIA e MATTIAZZO (1976a) em experimentos de incubação onde observaram que pela adição de vinhaça 0 pH do substrato (solo + areia) inicialmente caia (de 5,3 para 4,3), mas de corridos 10 dias voltava ao nivel original e dai por diante crescia, podendo, em função do tempo e principalmente do volume de vinhaça aplicado ating ir valores superiores a 7,0 .

2.2.2. Efeito na disponibilidade de fósforo do solo

SHAPIRO (1958), BEAR (1964), TISDALE e NELSON (1966), MALAVOLTA (1967), BARBER (1968), BUCKMAN e BRADY (1968), SINHA (1972), MALAVOLTA (1976), relatam trabalhos em que a influência da matéria orgânica so bre a solubilização de fosfatos no solo se fez sentir atravēs do fornecimento de ācidos orgânicos capazes de solubilizar fosfatos ou ainda através da complexação de cātions metālicos por radicais orgânicos com a consequente liberação de fosfatos.

LARSEN (1968), observou que quando um fosfato insolūvel, ta? como hidroxiapatita, è formado na presença de matēria orgânica ele tem um diâmetro de particula muito menor do que aquele formado em ausência de matéria orgânica, o que aumentaria a solubilidade do fosfato formado em tais condições. Salientava ainda não ter explicações claras para explicar esse fato. 
Outros autores, entretanto, tem dedicado maior atenção à re lação entre conteūdo de matēria orgānica dos solos, microrganismos e solubilização de fösforo nesses solos. Nestes trabalhos a matēria orgānica tem sua principal importāncia no fato de ser fonte de energia para o desen volvimento de microrganismos do solo.

De acordo com KAILA (1949), DALTON et alii (1952), WAKSMAN (1952), STANFORD e PIERRE (1953), POCHON e BARJAC (1958), ALEXANDER (1961), BEAR (1964), DOMMERGUES e MANGENOT (1970), OTHIENO (1973), a solubilização de fosfatos por ação de microrganismos pode ser devida a diversos mecanismos:

- pela influência direta ou indireta de microrganismos hä produção de ácidos orgânicos e inorgânicos capazes de solubilizar fosfatos.

- pela influência direta ou indireta de microrganismos hä produção de certas substâncias orgānicas que são capazes de complexar cālcio, ferro e aluminio, de fosfatos libertando o citado ion na solução do solo.

- microrganismos são capazes de utilizar formas insolúveis de fösforo transformando-a em compostos orgânicos, chamados genericamente de fösforo microbiano. Esse fösforo, posteriormente, ē liberado sob formas capazes de serem absorvidas pelos vegetais.

EIRA e CARVALHO (1968) e CARVALHO et alii (1969), fizeram estudos visando a determinação dos microrganismos capazes de solubilizar fosfatos em solos tropicais e encontraram que enquanto as bactérias 
apresentam pequena capacidade solubilizadora, os fungos apresentaram solubilização muito boa, notadamente o fungo Aspergillus Niger. Tais resultados são entretanto, conträrios aos obtidos quando se trabalha em regiões temperadas onde se observa que as bactērias apresentam capacidade solubili zadora maior que a de fungos (MOREAU, 1959). Para essas regiões, inclusive, jă existem têcnicas de aproveitamento de fosfatos insolüveis pela inoculação dos mesmos com fosfobacterinas (bactērias solubilizadoras de fosfa tos) o que aumenta sensivelmente a produção de centeio, arroz, morangueiro, ervilha, trigo e cevada. ZAK e MUKHUTDINOV (1964); ZAREMBA et alii (1966); BARBER e LOUGHMAN (1967); BAJPAI e SUBBA-RAO (1971).

No que se refere à solubilização de fosfatos por fungos deve-se dar importância particular às associações entre fungos e raỉzes de plantas chamadas associações micorrizicas. Essas associações seriam res. ponsāveis por uma maior absorção de fósforo pelas plantas em função de uma maior ārea de absorção formada pelas hifas do fungo. (SUBBA-RAO e BAJPAI, 1965; RAMOS et alii, 1968; GRAY e GERDEMANN, 1969; HENDERSON e STONE,1970; MEJSTRIK, 1970; ROSS, 1971; JACKSON et alii, 1972; ROSS e GILLIAN, 1973).

BARBER (1968), verificou que em solução nutritiva, quando a concentração de fósforo no meio estā abaixo de 1 ppm de $P$, microrganismos fora e na raiz absorvem fósforo e incorporam-no principalmente em ácidos nucleicos reduzindo a quantidade disponivel ãs plantas. Em altas concentrações de fösforo a extensão desse efeito é menos pronunciada porēm não pode ser considerado insignificante uma vez que uma absorção de luxo de fósforo ocorre quando microrganismos erescem num meio com al to teor desse 
elemento. Essa absorção de luxo jā havia sido observada por WAKS:YAN (1924) citado por ENWEZOR (1966).

Quando um fertilizante fosfatado solūvel $\bar{e}$ adicionado ao solo, ele rapidamente perde sua solubilidade devido principalmente a fixações de natureza quỉmica e biolōgica. Das duas, a fixação quỉmica tem recebido maiores atenções como bem atestam o número de trabalhos publicados a esse respeito, porém fixação biolögica, frequentemente referida como imobilização pode ser de importāncia especialmente quando se incorpora materiais orgânicos á solos sem fertilização fosfatada suplementar e, mesmo quando essa fertilização e aplicada a imobilização pode ser de importância superior à fixação quîmica porque resulta numa completa "perda" do fösforo imobilizado (KAILA, 1949; ENWEZOR, 1966). ENWEZOR (1976) salienta que a rapidez da imobilização e a relação entre mineralização e fösforo orgânico formado pode determinar efeitos a curto e a longo prazo desse fenômeno, is to é, durante a decomposição do material orgânico adicionado ao solo hä uma intensa absorção pelos microrganismos do fósforo solūvel adicionado ao solo. Com o decorrer do tempo (12 semanas) jă se pode observar a mineralização do fósforo. Como fonte de matéria orgānica, o autor usou grama seca, grama moida e palha de ervilha.

Alēm da concentração de fösforo, outros fatores que influen ciam a atividade microbiana são pH e fonte de matēria orgānica fornecida como substrato aos microrganismos (KAILA, 1949; ALEXANDER, 1961; BARBER, 1968; LAI e OKAZAKI, 1970; BAJPAI e SUBBA-RAO, 1971a; ENWEZOR, 1976).

Sob este segundo aspecto GLORIA et alij, (1976) e GLORIA e MATTIAZzo (1976a) estudaram o efeito da matéria orgânica proveniente da 
torta de mamona, bagaço de cana, torta de filtro e vinhaça (estes três ūltimos residuos de usinas de açūcar e destilarias), na solubilização de fos fatos no solo em experimentos de laboratório tipo Neubauer e concluiram que, nas condições experimentais não houve efeito benéfico das citadas fon tes de matéria orgânica na solubilização de fosfatos no solo; o que concor da com os resultados obtidos por JELNIC e MAJDUKOVIC (1965); BLACK e REITH (1972); NISHITA et alii. (1973).

2.2.3. Efeito no poder de retenção de cátions pelo solo

VERDADE (1956); PRATT (1966); TISDALE e NELSON (1966); BUCKMAN e BRADY (1968); VAN RAIJ (1969); JORGE (1972); WUTKE e CAMARGO (1972); MALAVOLTA (1976), são unānimes em afirmar que uma das propriedades quỉmicas da matéria orgânica de maior importância é sua alta capacidade de retenção de cātions.

VAN RAIJ (1969) estudando a capacidade de troca catiōnica da fração orgânica e mineral de solos tropicais observou, que a porcentagem média da CTC devida à matéria orgânica era de $74 \%$ em horizontes superficiais, decrescendo com a profundidade acompanhando o teor de matéria orgânica. Ainda o mesmo autor observa que a maior capacidade de troca de matéria orgânica em solos com pH mais alto, podia ser devida, além da maior ionização de radicais carboxîlicos e fenōlicos, à existência de melhores condições para a atividade microbiana e como consequência haveria uma maior evolução da matéria orgānica do solo propriamente dita. GLÖRIA e MAGRO (1976) em estudos realizados na Usina da Pedra (SP) sobre a utilização agrīcola da vinhaça observou a elevação da capacidade de troca de cātions dos solos tratados com vinhaça, elevação esta 
proporcionada seja pelo aumento do teor de matéria orgânica do solo, seja pelo fornecimento de ions $\mathrm{Ca}^{2+}, \mathrm{Mg}^{2+}$ e $\mathrm{K}^{+}$trocāveis. Observações semel han tes jā haviam sido feitas por VALSECCHI e GOMES (1954) e VALSECCHI (1955) no que diz respeito aos valores $S$ e $T$ (respectivamente soma de bases e total de bases) de solos tratados com vinhaça.

\subsubsection{Efeito na população e atividade microbiana do solo}

De acordo com WA KSMAN (1952); ALEXANDER (1961); BUCKMAN e BRADY (1968); STANIER et alii (1969); DOMMERGUES e MANGENOT (1970) os microrganismos do solo são capazes de utilizar materiais orgânicos nele presentes como fonte de energia e fonte de carbono para sintese de seu material celular. Ainda segundo esses autores desde que outros elementos nutritivos não estejam ausentes, 0 aumento no teor de matériais orgânicos do solo provoca um crescimento acentuado de sua população microbiana.

ALEXANDER (1961) observa que a quantidade e tipo de matéria orgānica natural ou adicionada ao solo determina o tamanho e a espécie da população microbiana que ele irā conter, por exemplo, o autor observou que quando adubos verdes eram incorporados ao solo, havia crescimento do numero de bactérias neste solo; colheitas maduras aumentavam a população de fungos e o uso de coberturas mortas aumentava indistintamente a população de fungos, bactérias e actinomicetos sendo esses aumentos proporcionais à quantidade de materiais orgānicos adicionados. Essas observações foram posteriormente confirmadas por LAI e OKAZAKI (1970) e ENWEZOR (1976).

BARBER (1968) e DOMMERGUES e MANGENOT (1970) salientam um outro fator que determina a espécie da população microbiana presente no 
solo e esse fator é o pH do solo. Neste aspecto observam que os fungos de senvolvem-se melhor em solos ácidos que em solos neutros ou alcalinos. Essa predominância de fungos em solos com pH menor que 5,0 não é devido ao fato de que eles encontrem condições ótimas de crescimento mas, à redução da concorrência de actinomicetos e bactērias que suportam menos a acidez.

ALMEIDA (1953); CAMARGO (1954) verificaram que a vinhaça quando aplicada a um solo aumenta espantosamente sua quantidade de microrganismos com predomināncia dos fungos Neurospora spp; Aspergillus. spp; Penicillium spp; Mucor spp e streptomices spp. Ainda CAMARGO (1954) obser vou que quando a vinhaça é aplicada a um solo de alta fertilidade a elevação no número de microrganismos è maior comparativamente ao resultante da aplicação de igual volume de vinhaça em um solo de baixa fertilidade.

Outros efeitos da matēria orgânica em geral ề da vinhaça em particular quando aplicados ao solo são encontrados na literatura porēm não são mencionados nesta revisão em virtude de não apresentarem interesse para a presente dissertação.

Os efeitos da vinhaça aqui mencionados são considerados como decorrentes do potencial de corretivo orgânico que ela possue e sō devem ser encarados quando se aplica quantidades elevadas de residuo ao so10. De acordo com GLORIA (1977c) para doses da ordem e $30-50 \mathrm{~m}^{3} /$ ha de vinhaça de mosto de melaço e de atē $100 \mathrm{~m}^{3} /$ ha das vinhaças de mosto misto e de caldo não se deve fazer tal colocação, pois nesses casos a adição da ma téria orgânica atravēs da vinhaça não é suficiente para que haja uma ação mais efetiva da matéria orgânica, pelo menos a curto prazo. 


\subsection{Métodos de fracionamento para fósforo em solos.}

Um modo de se avaliar sob que forma o fósforo está presente no solo é atravēs do fracionamento das vārias formas seguindo a metodologia de extrações sucessivas proposta por CHANG e JACKSON (1957a) que, em bora sujeita a criticas, tem sido uma maneira de se estudar a quantidade dos vārios fosfatos inorgānicos do solo, seu modo de formação, seu transporte pelas plantas e suas relações com o tipo de solo (SMITH, 1969). 0 mē todo de fracionamento de CHANG e JACKSON (1957a) consiste, basicamente, de uma sērie de extrações sucessivas do solo com: solução normal de $\mathrm{NH}_{4} \mathrm{Cl}$ para extrair formas solūveis de fosfato; solução $0,5 \mathrm{~N}$ de $\mathrm{NH}_{4} \mathrm{~F}$ pH 7,0 para extrair fosfatos de aluminio; solução $0,1 N$ de $\mathrm{NaOH}$ para extrair fosfatos de ferro; solução $0,5 \mathrm{~N}$ de $\mathrm{H}_{2} \mathrm{SO}_{4}$ para extrair fosfatos de cālcio. A esta sērie de quatro extrações em sequência segue-se a redução com ditionito de sōdio e extração dos fosfatos de ferro oclusos com citrato de sōdio, apōs o que è feita uma nova extração com $\mathrm{NH}_{4} \mathrm{~F} \quad 0,5 \mathrm{~N}$ para extração de fosfatos de aluminio oclusos.

A principal critica ao método de fracionamento de CHANG e JACKSON è a que diz não haver uma separação nittida entre o fósforo ligado ao aluminio e o fösforo ligado ao ferro e sobre esse aspecto 0 trabalho original de CHANG e JACKSON (1957a) observava que uma pequena porcentagem de fosfato de ferro era dissolvida pela solução $0,5 \mathrm{~N}$ de $\mathrm{NH}_{4} \mathrm{~F}$. Para corrigir essa inconveniência do método sugeriam que uma segunda extração com a citada solução devia ser feita e à quantidade de fósforo obtida nessa segunda extração deveria ser subtraỉda da quantidade de fósforo ligado ao aluminio obtida na primeira extração. A quantidade de fósforo obtida na 
segunda extração com solução $0,5 \mathrm{~N}$ de $\mathrm{NH}_{4} \mathrm{~F}$, multiplicada por dois e somada ao total de fósforo obtido na extração com $\mathrm{NaOH}$ fornece a quantidade de fósforo ligado ao ferro.

FIFE (1962) observou que a solução 0,5N de $\mathrm{NH}_{4} \mathrm{~F}$ pH 7,0 usada por CHANG e JACKSON (1957a) podia também dissolver fösforo ligado ao ferro dando um errōneo alto valor para o fósforo ligado ao alumīnio mas podia haver também um efeito oposto, isto é, os fosfatos de aluminio dis solvidos na solução $0,5 \mathrm{~N}$ de $\mathrm{NH}_{4} \mathrm{~F}$ pH 7,0 podiam ser adsorvidos nas superfi cies de óxidos de ferro livres do solo. Sugeriu então que uma solução alcalina de $\mathrm{NH}_{4} \mathrm{~F}(\mathrm{pH} 8,5)$ seria suficiente para inibir esse fenōmeno. Uma solução $0,5 \mathrm{~N}$ de $\mathrm{NH}_{4} \mathrm{~F}$ pH 8,5 passou a ser usada por diversos autores e entre eles, FIFE (1963), WILLIANS et alii. (1967), CATANI e BATAGLIA (1963).

0 trabalho de FIFE (1962) foi contestado por CHANG e LIAW (1962) que afirmam que $0 \mathrm{pH}$ da solução de $\mathrm{NH}_{4} \mathrm{~F}$ entre 7,0 e 3,5 não afeta de modo significativo a quantidade de fösforo extraỉdo.

$\mathrm{Na}$ extração do solo com $\mathrm{NaOH} 0,1$ in para determinação do fós foro ligado ao ferro, acha-se incluida uma fração variāvel do fösforo orgânico (CATANI e BATAGLIA, 1968). Ainda esses autores a fim de estudar a extração de fósforo ligado ao ferro com solução de $\mathrm{NaOH} 0,1 N$, submeteram amostras de um mesmo solo latossōlico à extrações sucessivas com soluções de $\mathrm{NH}_{4} \mathrm{Cl}, \mathrm{NH}_{4} \mathrm{~F}$ e a seguir procederam a um estudo do tempo de agitação com solução de $\mathrm{NaOH} 0,1 N$, observando que duas extraçōes sucessivas com 3 horas de agitação extraỉram mais fósforo do que uma única extração de 24 ho ras. Esse fato pode ser atribuido a uma maior extração de fösforo orgānico, 
formas de fósforo ocluso e principalmente fosfatos de cālcio (CHANG e JACKSON, 1957a; CHANG e CHU, 1961).

Todavia problemas dos mais sérios dizem respeito aos fosfatos de cālcio. De acordo com PATEL e MEHTA (1961), PRATT, (1966), a solução $0,5 \mathrm{~N}$ de $\mathrm{NH}_{4} \mathrm{~F}$ é capaz de dissolver $90 \%$ de fosfato de cälcio dihidrata do $\left(\mathrm{CaHPO}_{4} \cdot 2 \mathrm{H}_{2} \mathrm{O}\right)$ e $85 \%$ de fosfato octocálcico. 0 composto $\mathrm{CaF}_{2}\left(\mathrm{HPO}_{4}\right) \cdot 5 \mathrm{H}_{2} \mathrm{O}$ apresentou-se com $20 \%$ solūvel em $\mathrm{NH}_{4} \mathrm{~F}, 60 \%$ em NaOH e $20 \%$ em $\mathrm{H}_{2} \mathrm{SO}_{4}$. Portanto se o fósforo no solo atingiu as formas mais estáveis de apatita, variscita e strengita o processo as fraciona nestas formas, mas se o solo tiver sido fertilizado recentemente e contiver formas mais solüveis de fosfato 0 processo não as diferencia muito bem. Esse fato è explicado pelo fato de que o fosfato recentemente precipitado no solo tem um tamanho de partícula e estrutura cristalina diferente quando comparado com compostos precipitados há mais tempo. Tais diferenças afetam a solubilidade dos compostos de fösforo. (LAVERTY e MCLEAN, 1961; BITTENCOURT e MONTANHEIRO, 1975).

Tendo em vista o que foi exposto nesta revisão bibliogräfica pode-se concluir que:

A - Materiais orgânicos adicionados ao solo (com especial destaque para a vinhaça) causam um aumento na sua capacidade de troca catiōnica (CTC) e no seu valor pH, sendo esse ültimo efeito conträrio àquele relatado na literatura clāssica.

B - A forma de fósforo predominante em um determinado solo ë função de seu pH e da presença de compostos de ferro, alumỉnio e cálcio 
nesse solo. Se houver uma elevação de pH como a que é provocada pela adi ção de vinhaça a esses solos, o que se espera é um comportamento do fósfo ro com tendência a uma maior precipitação sob forma de compostos de ferro, aluminio e cálcio.

C - A adição de materiais orgânicos ao solo influencia a quantidade e a qualidade de sua população microbiana (este ūltimo sendo função do $\mathrm{pH}$ do solo) e isso poderā ter os seguintes efeitos sobre o fōsforo mineral presente no solo:

- O efeito imediato é a imobilização do fósforo. Microrganismos são capazes de utilizar o fósforo presente no solo para a constituição de seu prōprio material celular, causando com isso imobilização do fósforo (ou como preferem alguns autores fixações de natureza biológica), esse fósforo poderā ser liberado em formas aproveitāveis para as plantas a curto ou a longo prazo.

- O efeito imediato é a solubilização do fósforo. Pela ação direta ou indireta dos microrganismos poderā haver a solubilização de formas menos solūveis de fósforo.

D- Apesar de todas as inconveniēncias que são atribuidas ao método de fracionamento de CHANG e JACKSON (1957a), ele foi o método escolhido para se estudar o comportamento do fósforo no solo após a adição de vinhaça, uma vez que o objetivo principal do presente trabalho $\vec{e}$ o de comparar os níveis das vārias formas de fósforo e não a quantidade absoluta das mesmas. 
25.

\section{MATERIAL E METODOS}

\subsection{Material.}

Foram empregados dois tipos de solos: Regossol sērie Sertãozinho e Latossol sērie Iracema cujas caracterîsticas quỉmicas determinadas de acordo com CATANI e JACINTHO (1974) acham-se no Quadro 1.

Algumas caracteristicas dos solos segundo RANZANI et alii. (1966) são descritas no Quadro 2.

Como fonte de fosfato solūvel foi usado o $\mathrm{Ca}\left(\mathrm{H}_{2} \mathrm{PO}_{4}\right)$ de pureza analitica e como fonte de fosfato insolüvel foi usado o fosfato Alvorada, cuja anālise de seus teores em $\mathrm{P}_{2} \mathrm{O}_{5}$ total e solúvel em àgua revelou os valores apresentados pelo Quadro 3.

A vinhaça usada no experimento foi obtida na Usina Monte Alegre e sua anālise mostrou:

$$
\begin{aligned}
& \text { Carbono }(\% \mathrm{C})=1,57 \\
& \text { Fósforo }\left(\% \mathrm{PO}_{4}^{3-}\right)=0,02
\end{aligned}
$$


A quantidade de fosfato usada nos tratamentos foi de $25 \mathrm{mg}$ de $\mathrm{P}_{2} \mathrm{O}_{5} / 100 \mathrm{~g}$ de solo. Essa quantidade foi calculada para elevar o teor do fósforo do solo a um nível alto, aproximadamente 0,30 e.mg $\mathrm{PO}_{4}^{3} 7100 \mathrm{~g}$ so 10, de acordo com CATANI e JACINTHO (1974), supondo-se um aproveitamento de $25 \%$ do fósforo adicionado.

A vinhaça foi adicionada de modo a aumentar o teor de carbono do solo em $1 \%$.

Quadro 1. Anālise quỉmica dos solos empregados

\begin{tabular}{|c|c|c|}
\hline Solo & Regossol & Latossol \\
\hline pH (suspensão $10 \mathrm{~g}$ solo/25ml àgua) & 5,00 & 5,20 \\
\hline Carbono (g/loog solo) & 0,68 & 1,88 \\
\hline Cālcio + Magnēsio (e.mg/loog solo) & 0,20 & 2,55 \\
\hline Potāssio (e.mg/100g solo) & 0,09 & 0,06 \\
\hline Hidrogènio trocāvel (e.mg/loog solo) & 0,25 & 0,35 \\
\hline Fösforo (e.mg $\mathrm{PO}_{4}^{3-} / 100 \mathrm{~g}$ solo) & 0,06 & 0,04 \\
\hline
\end{tabular}

\subsection{Montagem do experimento,}

Em recipientes de plāstico foram colocados $250 \mathrm{~g}$ de solo e nos tratamentos com fosfato insolüvel, esse solo foi intimamente misturado com $181,11 \mathrm{mg}$ de fosfato Alvorada. O fosfato solüvel, $\mathrm{Ca}\left(\mathrm{H}_{2} \mathrm{PO}_{4}\right)_{2}$, foi adicionado na forma de uma solução que continha $116,28 \mathrm{mg}$ de $\mathrm{P}_{2} \mathrm{O}_{5}$ em 
$10 \mathrm{ml}$ da solução. Nos tratamentos que continham vinhaça, colocou-se $160 \mathrm{ml}$ em cada recipiente. A proporção de água adicionada foi de $30 \% \stackrel{\text { em }}{0}$ peso do solo (75g de àgua).

Quadro 2. Algumas caracterỉsticas dos solos empregados (segundo RANZANI et alii, 1966)

\begin{tabular}{|c|c|c|c|c|}
\hline & $\begin{array}{l}\text { Profundidade } \\
\qquad \mathrm{cm}\end{array}$ & Horizonte & $\begin{array}{c}\text { Relaçãa } \\
\mathrm{C} / \mathrm{N}\end{array}$ & $\begin{array}{l}\text { Oxido de } \\
\text { ferro livre } \\
\% \mathrm{Fe}_{2} \mathrm{O}_{3}\end{array}$ \\
\hline Regossol & $0-25$ & $A p$ & 8 & 2,8 \\
\hline sērie & $25-75$ & $c_{1}$ & 8 & 2,3 \\
\hline Sertãozinho & $95-250$ & $c_{2}$ & 4 & 2,1 \\
\hline Latossol & $0-20$ & $A p$ & 17 & 21,1 \\
\hline sērie & $20-55$ & $A_{12}$ & 23 & 21,1 \\
\hline \multirow[t]{3}{*}{ Iracema } & $55-115$ & $A_{3}$ & 23 & 20,9 \\
\hline & $115-225$ & $B_{1}$ & 23 & 18,7 \\
\hline & +225 & $B_{2}$ & 10 & 21,4 \\
\hline
\end{tabular}


Quadro 3. Anālise dos fosfatos utilizados no experimento

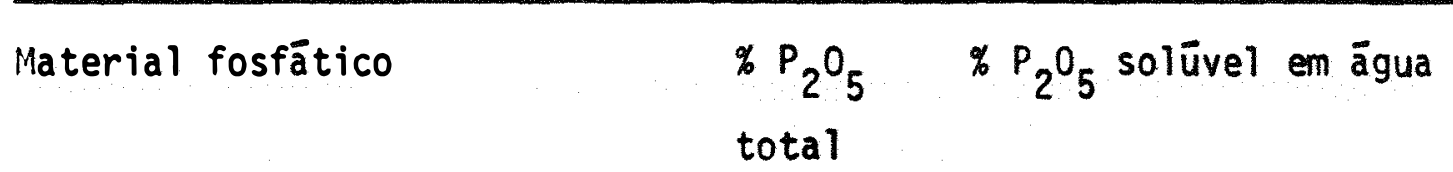

\begin{tabular}{llr}
\hline Fosfato Alvorada (a) & 34,51 & $<0,01$ \\
$\mathrm{Ca}\left(\mathrm{H}_{2} \mathrm{PO}_{4}\right)_{2}$ & 53,75 & 53,75
\end{tabular}

(a) o fosfato alvorada apresentou um tamanho de partícula de 100-150 mesh.

0 esquema da montagem do experimento acha-se no Quadro 4.

Nos tratamentos com vinhaça houve excesso de āgua no inīcio, porque a quantidade de vinhaça necessäria para elevar o teor de carbono do solo em $1 \%$ era al ta devido ao baixo teor do elemento nela existen te. Essa dificuldade foi contornada, em poucos dias, com a evaporação.

Periodicamente foram retiradas amostras nas quais foram

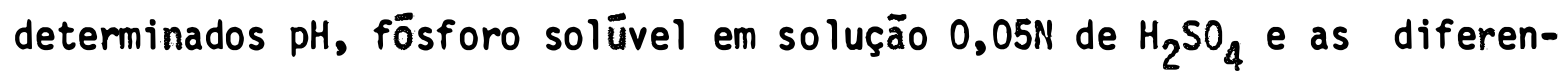
tes formas de fósforo. 
Quadro 4. Esquema da montagem do experimento

\begin{tabular}{|c|c|c|}
\hline \multicolumn{2}{|c|}{ Tratamentos } & \multirow[b]{2}{*}{ Componentes } \\
\hline Nọ & $\begin{array}{c}\text { Representação } \\
\text { esquemātica }\end{array}$ & \\
\hline 1 & R & Regossol + āgua \\
\hline 2 & L & Latossol + ägua \\
\hline 3 & $R+V$ & Regossol + vinhaça + āgua \\
\hline 4 & $L+V$ & Latossol + vinhaça + āgua \\
\hline 5 & $R+V+P_{S}$ & Regossol + vinhaça + fosfato solūvel + āgua \\
\hline 6 & $L+V+P_{S}$ & Latossol + vinhaça + fosfato solūvel + āgua \\
\hline 7 & $R+V+P_{i}$ & Regossol + vinhaça + fosfato insolūvel + àgua \\
\hline 8 & $L+V+P_{i}$ & Latossol + vinhaça + fosfato insolüvel + āgua \\
\hline 9 & $R+P_{s}$ & Regossol + fosfato solūvel + àgua \\
\hline 10 & $L+P_{S}$ & Latossol + fosfato solūvel + ägua \\
\hline 11 & $R+P_{i}$ & Regossol + fosfato insolūvel + āgua \\
\hline 12 & $L+P_{i}$ & Latossol + fosfato insolūvel + āgua \\
\hline
\end{tabular}




\subsection{Métodos}

Para a determinação do pH e do fósforo solūvel em solução $0,05 \mathrm{~N}$ de $\mathrm{H}_{2} \mathrm{SO}_{4}$ foi usado o método de CATANI e JACINTHO (1974).

Os mētodos empregados para o fracionamento das värias formas de fösforo do solo são aqueles preconizados por CHANG e JACKSON (1957a) com algumas das alterações propostas por CATANI e BATAGLIA (1968). Todavia foram introduzidas novas modificações, apōs estudos prévios, e os métodos empregados são descritos a seguir.

Extração 1 - Determinação do fósforo solūvel em solução normal de $\mathrm{NH}_{4} \mathrm{Cl}$ que fornece o fósforo solūvel em āgua e outras formas fra camente ligadas ao solo.

Metodologia empregada na extração I - 0 método empregado foi idêntico ao descrito por CATANI e BATAGLIA (1968).

Extração II. - Determinação do fósforo solūvel em solução de $\mathrm{NH}_{4} \mathrm{~F} 0,5 \mathrm{~N}$ com pH 8,5 que, fornece o fósforo ligado ao alumīnio.

Metodologia empregada na extração II - 0 método empregado foi identido ao descrito por CATANI e BATAGLIA (1968), sendo feitas duas extrações sucessivas a fim de se calcular e corrigir a influência do fósforo 1 igado ao ferro. Deve-se, todavia, ressaltar a necessidade da adição de $5 \mathrm{ml}$ de àcido börico $0,8 \mathrm{M}$ para a complexação do fluoreto que impede o desenvolvimento da cor azul do complexo entre o fósforo e o molibdênio do reativo sulfo-bismuto-mol ibdico. 
Extração III - Determinação do fósforo solūvel em solução de $\mathrm{NaOH} 0,1 \mathrm{~N}$ a fim de obter o fósforo ligado ao ferro.

\section{Metodologia empregada na extração III}

\section{Obtenção da curva padrão}

a. Transferiu-se 0,$25 ; 0,5 ; 1,0 ; 3,0 ;$ e $4,0 \mathrm{ml}$ de solução padrão contendo $10 \mathrm{ppm}$ de $P$, para balōes volumētricos de $50 \mathrm{ml}$.

b. Adicionou-se a cada balão $10 \mathrm{ml}$ de solução de $\mathrm{NaOH} 0,1 \mathrm{~N}$ e neutralizou-se com solução de $\mathrm{H}_{2} \mathrm{SO}_{4} 5 \mathrm{~N}$ atē descorar a fenolftaleỉna.

c. A seguir, adicionou-se $10 \mathrm{ml}$ de solução sulfo-bismutomolíbdico e lml de àcido ascōrbico 3\%, agitando-se apōs adição de cada reativo. 0 volume foi completado com água destilada e homogeneizou-se a solução. A leitura foi feita 10 minutos apōs a adição do ūltimo reativo usando-se colorimetro Lange com filtro vermelho.

\section{Método para o solo,}

a. O solo contido no tubo de centrîfuga apōs extração II

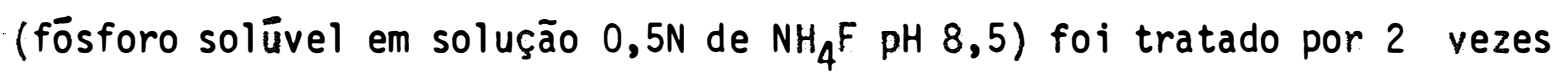
consecutivas, com $25 \mathrm{ml}$ de solução saturada de $\mathrm{NaCl}$, removendo-se e rejeitando-se o liqquido sobrenadante apōs cada agitação (15 minutos) seguida de centrifugação (5 minutos a 2500-3000 rpm).

b. Adicionou-se ao solo contido no tubo de centrífuga $50 \mathrm{ml}$ de solução de $\mathrm{NaOH} 0,1 \mathrm{~N}$ arrolhou-se e agitou-se durante 3 horas. 
c. A suspensão foi centrifugada durante 15 minutos a 2500-3000 rpm, foi recentrifugada quando necessärio, separou-se e conservou-se o sobrenadante.

d. Foi feita uma segunda extração com solução de $\mathrm{NaOH} 0,1 N$ e reservou-se o solo para a extração IV.

e. Foram transferidos $10 \mathrm{ml}$ do sobrenadante obtido em c ou d para outro tubo de centrífuga. Neutralizou-se com $\mathrm{H}_{2} \mathrm{SO}_{4} 5 \mathrm{~N}$ até descorar a fenolftaleina. Adicionou-se mais $1,5 \mathrm{ml}$ de $\mathrm{H}_{2} \mathrm{SO}_{4}$ e esperou-se até os colóides do solo precipitarem.

f. A suspensão obtida em e foi centrifugada durante 5-10 minutos atē a deposição do material sōlido.

g. Transferiu-se o sobrenadante para balão volumétrico de $50 \mathrm{ml}$ e neutralizou-se com solução de $\mathrm{NaOH} 5 \mathrm{~N}$ em presença de fenolftaleina. A seguir procedeu-se conforme item $c$ da obtenção da curva padrão na extração III.

h. Calculou-se a concentração de fósforo em ppm de $P$ no so 10 atravēs de equações de regressão, somando-se os resultados obtidos nas duas extraçōes com $\mathrm{NaOH} 0,1 \mathrm{~N}$. A esse resultado somava-se ainda duas vezes a quantidade de fósforo extraỉda na 2a. extração com $\mathrm{NH}_{4} \mathrm{~F} \quad 0,5 \mathrm{~N} \mathrm{pH} \mathrm{8,5.}$

Extração IV - Determinação do fósforo solūvel em solução de $\mathrm{H}_{2} \mathrm{SO}_{4} 0,5 \mathrm{~N}$, a fim de obter o fósforo ligado ao cālcio. 


\section{Metodologia empregada na extração IV}

Obtenção da curva padrão.

a. Transferiu-se 0,$25 ; 0,50 ; 1,0 ; 2,0 ; 3,0 ;$ e $4,0 \mathrm{ml}$ da solução padrão contendo 10 ppm de $P$ para balões volumétricos de $50 \mathrm{ml}$.

b. Adicionou-se $25 \mathrm{ml}$ de solução de $\mathrm{H}_{2} \mathrm{SO}_{4} 0,5 \mathrm{~N}$ a cada um dos balões e neutralizou-se com NaOH $5 \mathrm{~N}$ em presença de fenolftaleĩna.

c. Adicionou-se, ainda, $10 \mathrm{ml}$ do reativo sulfo-bismuto-molíbdico, Iml de ācido ascōrbico a 3\%, agitando-se apōs a adição de cada reativo. Completou-se o volume e homogeneizou-se. A leitura foi feita 10 minutos apōs a adição do ültimo reativo usando-se colorỉmetro Lange com filtro vermelho.

\section{Método para o solo.}

a. O solo contido no tubo da centrífuga, apōs a extração III, foi tratado por 2 vezes consecutivas, com $25 \mathrm{ml}$ de solução saturada de $\mathrm{NaCl}$, removendo-se e rejeitando-se o líquido sobrenadante apōs cada agitação (15 minutos) seguida de centrifugação (5 minutos a 2500-3000rpm).

b. Foi adicionado, ao solo contido no tubo, $50 \mathrm{ml}$ de solução $0,5 \mathrm{~N}$ de $\mathrm{H}_{2} \mathrm{SO}_{4}$, arrolhou-se e agitou-se durante uma hora.

c. A suspensão foi centrifugada durante 5 minutos atē 0 líquido sobrenadante ficar claro, is to é, livre de material em suspensão, o sobrenadante foi separado e conservado. 
d. Procedeu-se a uma segunda extração com solução $\quad \mathrm{H}_{2} \mathrm{SO}_{4}$ $0,5 \mathrm{~N}$ e reservou-se o solo para a extração $\mathrm{V}$.

e. Transferiu-se $25 \mathrm{ml}$ do líquido sobrenadante (ítem $\mathrm{c}$ ou item d para balão volumétrico de $50 \mathrm{ml}$ e neutralizou-se em presença de fenolftaleina, com $\mathrm{NaOH} 5 \mathrm{~N}$.

f. Procedeu-se a seguir conforme o indicado pelo item c da obtenção da curva padrão da extração IV. Calculou-se a concentração do fósforo em ppm de $P$ no solo atravēs de equação de regressão, somandose os resultados obtidos nas duas extrações com $\mathrm{H}_{2} \mathrm{SO}_{4} 0,5 \mathrm{~N}$.

Extração V - Determinação do fósforo orgânico - 0 fósforo orgânico foi determinado por diferença entre o teor extraĩdo com solução de $\mathrm{H}_{2} \mathrm{SO}_{4} 0,5 \mathrm{~N}$ de amostra de solo submetida à ação de temperatura de $550^{\circ} \mathrm{C}$ durante uma hora e o teor extraĩdo pela mesma solução de $\mathrm{H}_{2} \mathrm{SO}_{4} 0,5 \mathrm{~N}$ de amostra de solo sem calcinar, de acordo com técnica preconizada por SAUNDERS e WILLIANS (1955) e também citado por CATANI e BATAGLIA (1968).

Extração VI. - Determinação do fósforo total

Metodologia empregada para a extração VI.

Obtenção da curva padrão.

a. Transferiu-se 0,$25 ; 0,50 ; 1,0 ; 2,0 ; 3,0 \mathrm{ml}$ de solução padrão contendo $10 \mathrm{ppm}$ de $P$ para balöes volumétricos de $50 \mathrm{ml}$.

b. Adicionou-se 20-30ml de água destilada e neutralizou-se com NaOH $5 \mathrm{~N}$ em presença de fenolftaleina. 
c. Adicionou-se $10 \mathrm{ml}$ do reativo sulfo-bismuto-molïbdico, lml de solução de ácido ascōrbico a 3\%, agitando-se apōs cada adição. Com pletou-se o volume com āgua destilada e homogeneizou-se a solução. A leitura foi feita em colorimetro Lange com filtro vermelho.

\section{Método para o solo.}

a. Pesou-se 0,500g de terra fina seca em estufa e transferiu-se para tubo de centrifuga.

b. Adicionou-se $10 \mathrm{ml}$ de $\mathrm{HCl}, 3 \mathrm{ml}$ de $\mathrm{HNO}_{3}(6 \mathrm{ml}$ para o Latos sol) e $5 \mathrm{ml} \mathrm{de} \mathrm{H}_{2} \mathrm{SO}_{4}$.

c. Aqueceu-se brandamente até o desenvolvimento de fumos brancos. Após esfriamento do material foram adicionados 20-30ml de àgua destilada.

d. Filtrou-se a solução para balão volumétrico de $100 \mathrm{ml}$, la vando-se o kjeldahl e o filtro com āgua destilada. O volume foi completado e homogeneizou-se a solução.

e. Transferiu-se uma alíquota de $5 \mathrm{ml}$ da solução para balão volumétrico de $50 \mathrm{ml}$, neutralizou-se com NaOH $5 \mathrm{~N}$ em presença de fenolftaleîna e procedeu-se conforme ítem c da obtenção da curva padrão para a ex tração VI. Calculou-se a concentração de fōsforo total em ppm de $P$ no so 10 a través de equação de regressão. 


\section{RESULTADOS OBTIDOS E DISCUSSAOO}

Foram feitas 6 amostragens em cada tratamento no transcorrer do experimento que durou 183 dias. Os resultados obtidos na determinação do $\mathrm{pH}$ encontram-se no Quadro 5 para os tratamentos com Regossol e no Quadro 6 para os tratamentos com Latossol.

Quadro 5. Variação do $\mathrm{pH}$ do substrato, nos tratamentos com Regossol, durante 0 transcorrer do experimento.

\begin{tabular}{ccccccc}
\hline Tratamento & 30 & 60 & 91 & 122 & 151 & 183 \\
\hline 1 & 5,1 & 4,6 & 4,2 & 4,2 & 4,2 & 4,9 \\
3 & 6,5 & 7,3 & 7,7 & 7,8 & 7,6 & 7,5 \\
5 & 7,4 & 7,6 & 7,7 & 7,8 & 7,7 & 7,5 \\
7 & 6,8 & 7,4 & 7,8 & 7,9 & 7,7 & 7,5 \\
9 & 4,9 & 4,7 & 4,4 & 4,4 & 4,3 & 4,9 \\
11 & 5,1 & 4,9 & 4,5 & 4,5 & 4,4 & 4,9 \\
\hline
\end{tabular}


Quadro 6. Variação do pH do substrato nos tratamentos com Latossol, durante o transcorrer do experimento

\begin{tabular}{ccccccc}
\hline Tratamento & 30 & 60 & 91 & 122 & 151 & 183 \\
\hline 2 & & & & & & \\
\hline 4 & 6,9 & 5,0 & 4,9 & 4,9 & 4,7 & 5,1 \\
6 & 6,4 & 6,6 & 6,7 & 6,8 & 6,6 & 6,6 \\
8 & 6,5 & 6,7 & 6,7 & 6,8 & 6,6 & 6,6 \\
10 & 6,5 & 6,7 & 6,7 & 6,7 & 6,6 & 6,6 \\
12 & 5,0 & 5,0 & 5,0 & 4,9 & 4,8 & 5,1 \\
\hline
\end{tabular}

Pelos dados dos Quadros 6 e 7 observa-se que 183 dias apōs a adição de vinhaça 0 pH do Regossol passou de 5,0 para 7,5. Para o Latossol essa elevação foi de 5,2 para 6,6 . E de se notar também que 30 dias apōs a adição de vinhaça 0 pH do tratamento 3 (Regossol + vinhaça) foi menor que nos tratamentos 5 e 7 (Regossol + vinhaça + fosfato) o mesmo ocorrendo com o Latossol, sugerindo uma maior atividade microbiana quan do se adiciona juntamente com o material orgânico uma fonte de fósforo. Isso concorda com o observado por CAMARGO (1954) que relatou que a população microbiana è muito maior num solo fértil do que num de baixa fertilidade quando ambos são tratados com igual volume de vinhaça. O pH máximo em ambos os solos foi notado aos 122 dias apōs a adição de vinhaça. 
Com os resultados obtidos no fracionamento das diferentes formas de fósforo do solo foram construidas as Figuras $1,2,3,4$ e 5 as quais relacionam tratamento, formas de fósforo ligadas ao aluminio (P-Al), formas de fósforo ligadas ao ferro $(P-F e)$, formas de fósforo ligadas ao cálcio $(\mathrm{P}-\mathrm{Ca})$, pH e tempo da amostragem para os tratamentos com Regossol. As Figuras $6,7,8,9,10$ mostram as mesmas relações correspondentes aos tratamentos com Latossol. 
39.

Figura 1. $\mathrm{pH}$ e formas de fösforo nos tratamentos com Regossol apōs 30 dias do inicio do experimento

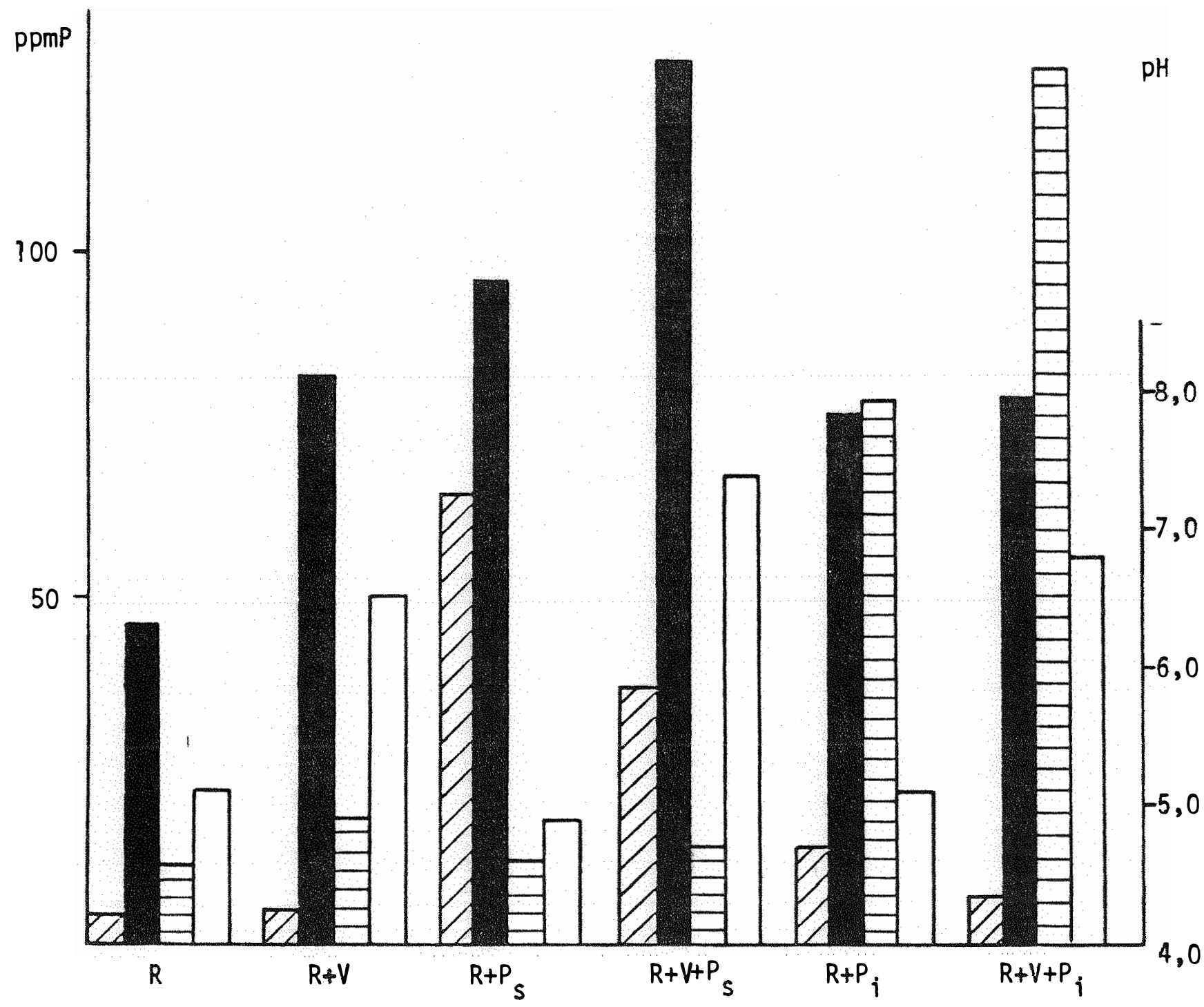

$\square=$ fósforo ligado ao aluminnio

= fósforo ligado ao ferro

$\Theta=$ fósforo ligado ao cālcio

$\square=\mathrm{pH}$ 
40.

Figura 2. $\mathrm{pH}$ e formas de fósforo nos tratamentos com Regossol apōs 60 dias do inicio do experimento

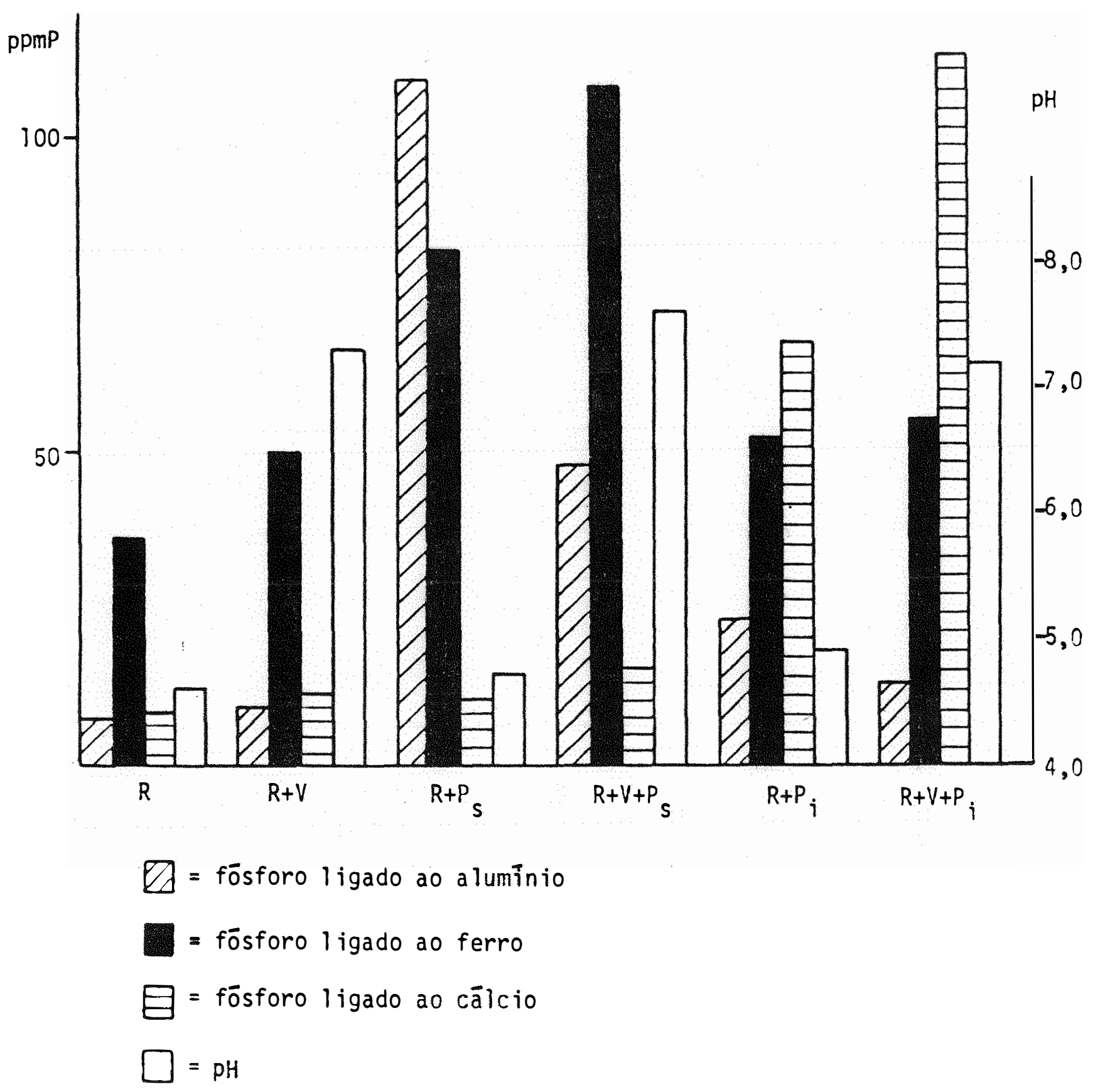


Figura 3. $\mathrm{pH}$ e formas de fósforo nos tratamentos com Regossol após 90 dias do inicio do experimento

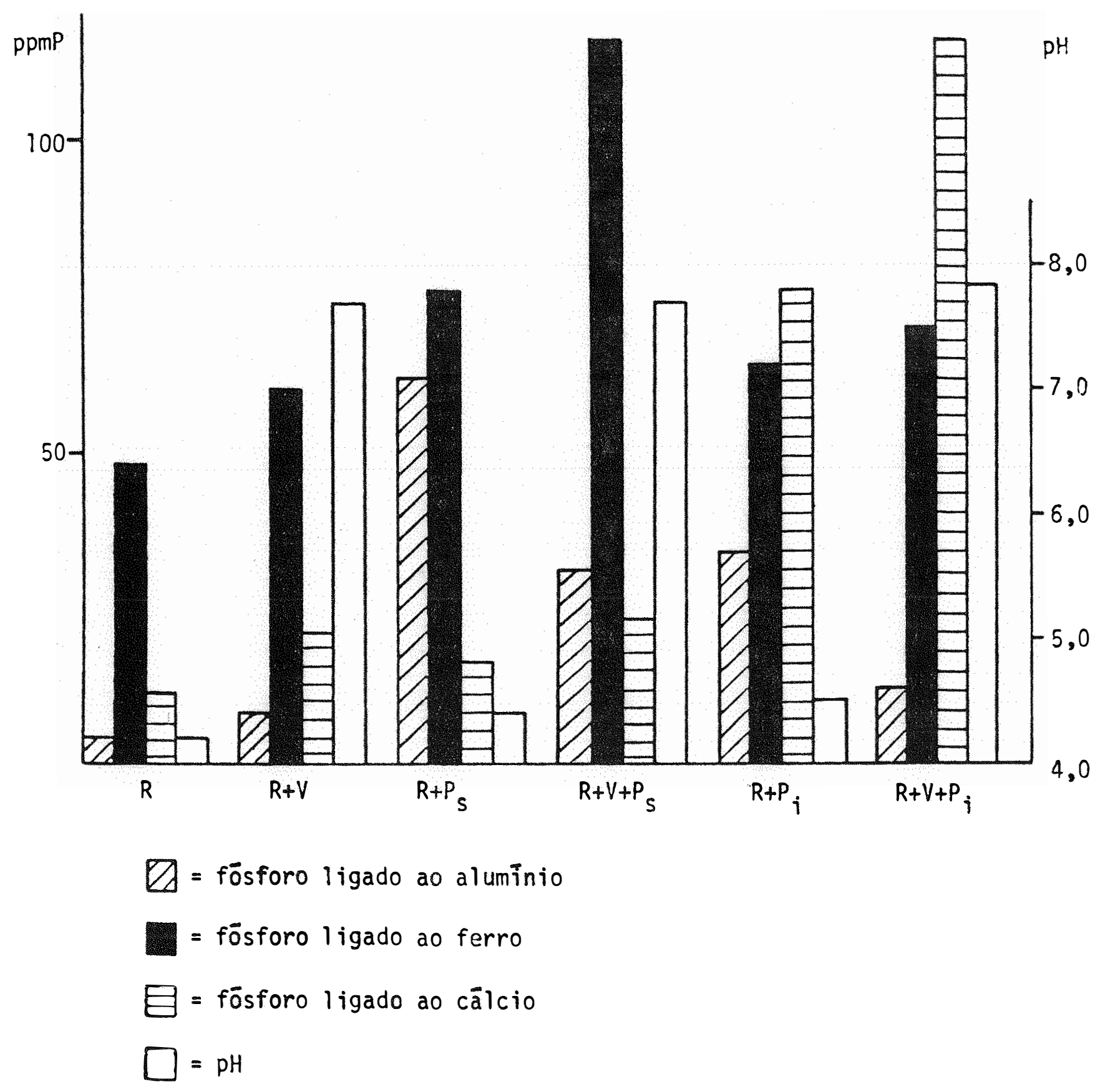


42.

Figura 4. pH e formas de fösforo nos tratamentos com Regossol apös 122 dias do inicio do experimento

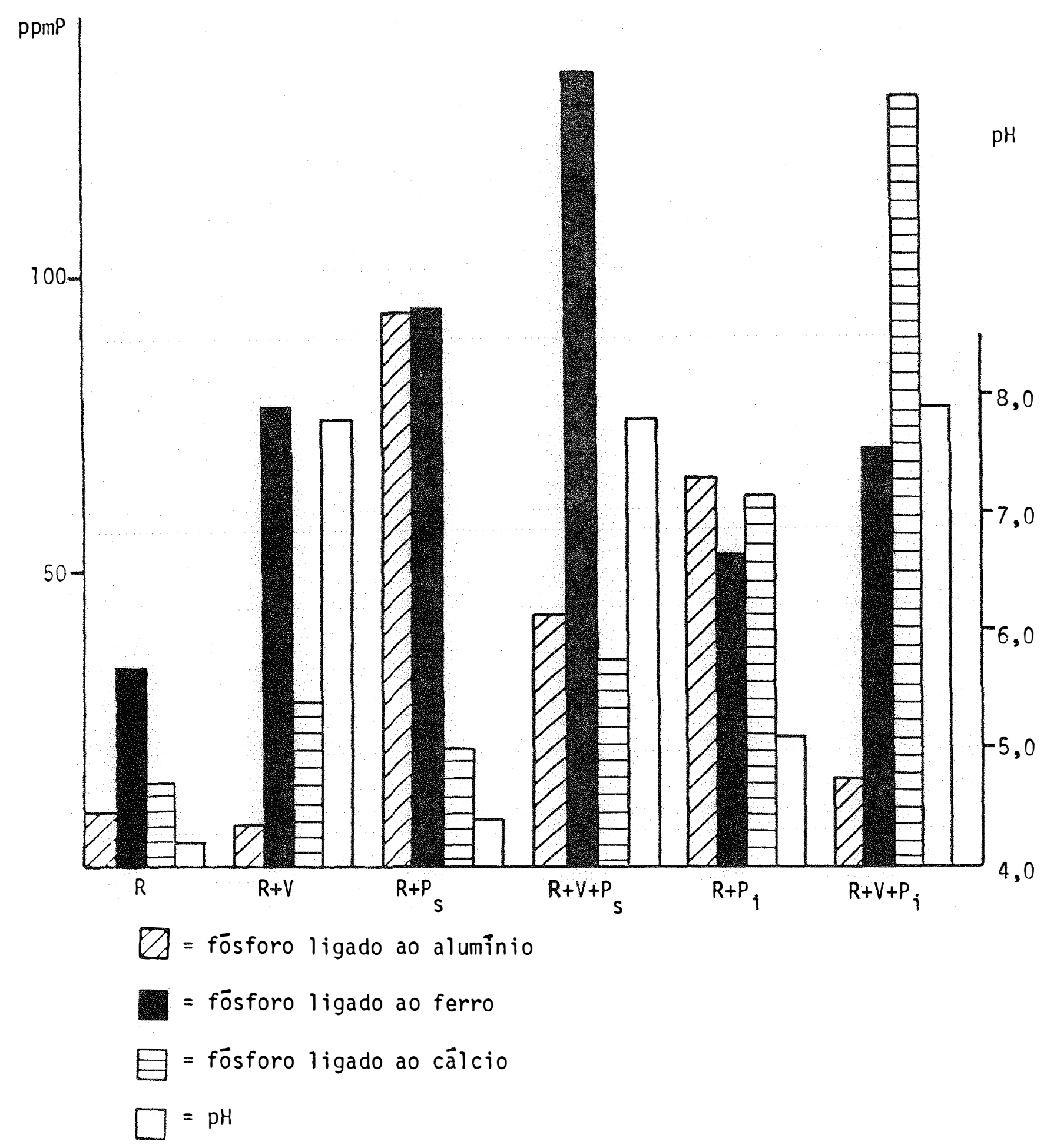


Figura 5. pH e formas de fósforo nos tratamentos com Regossol após 183 dias do inicio do experimento

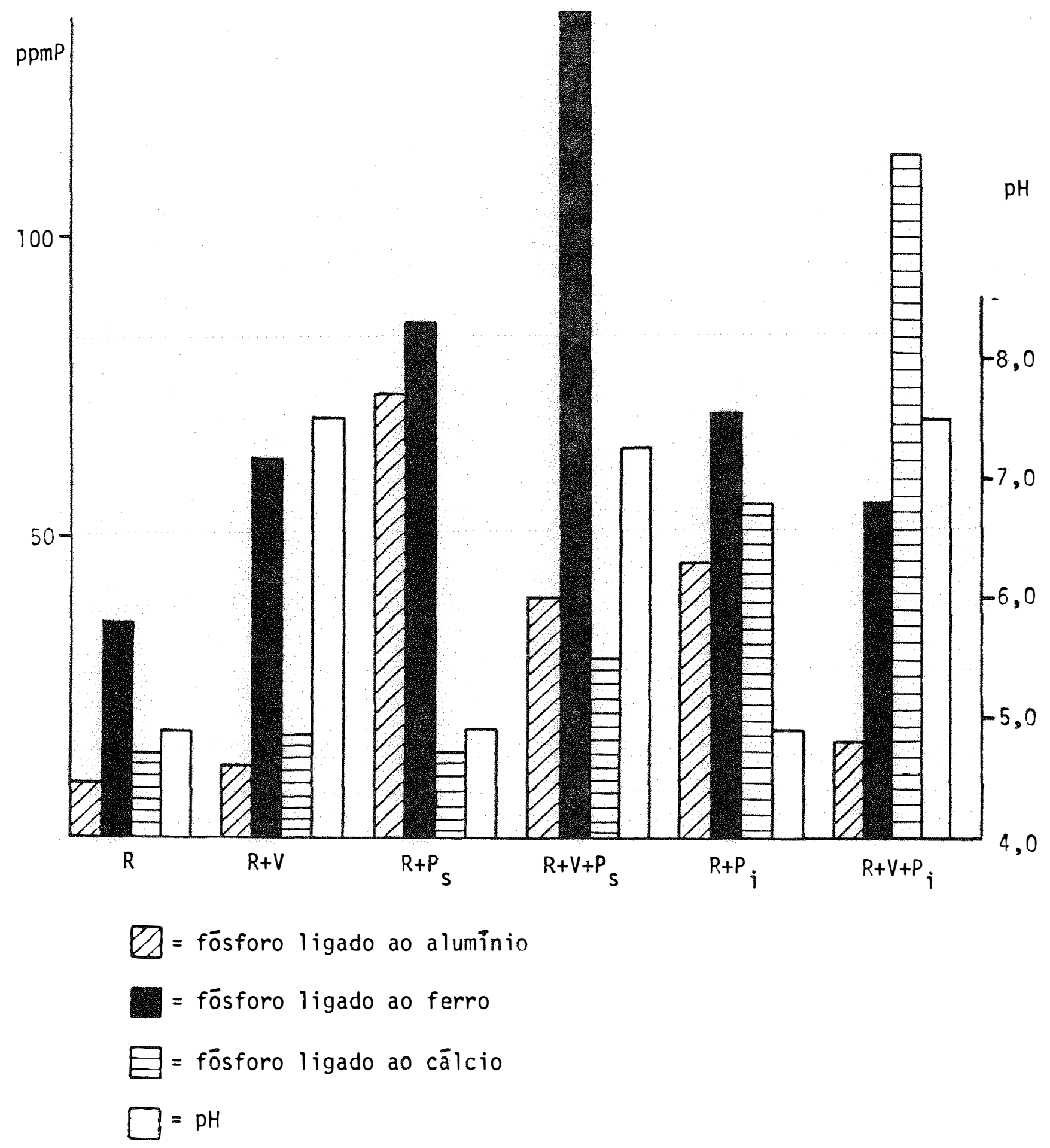




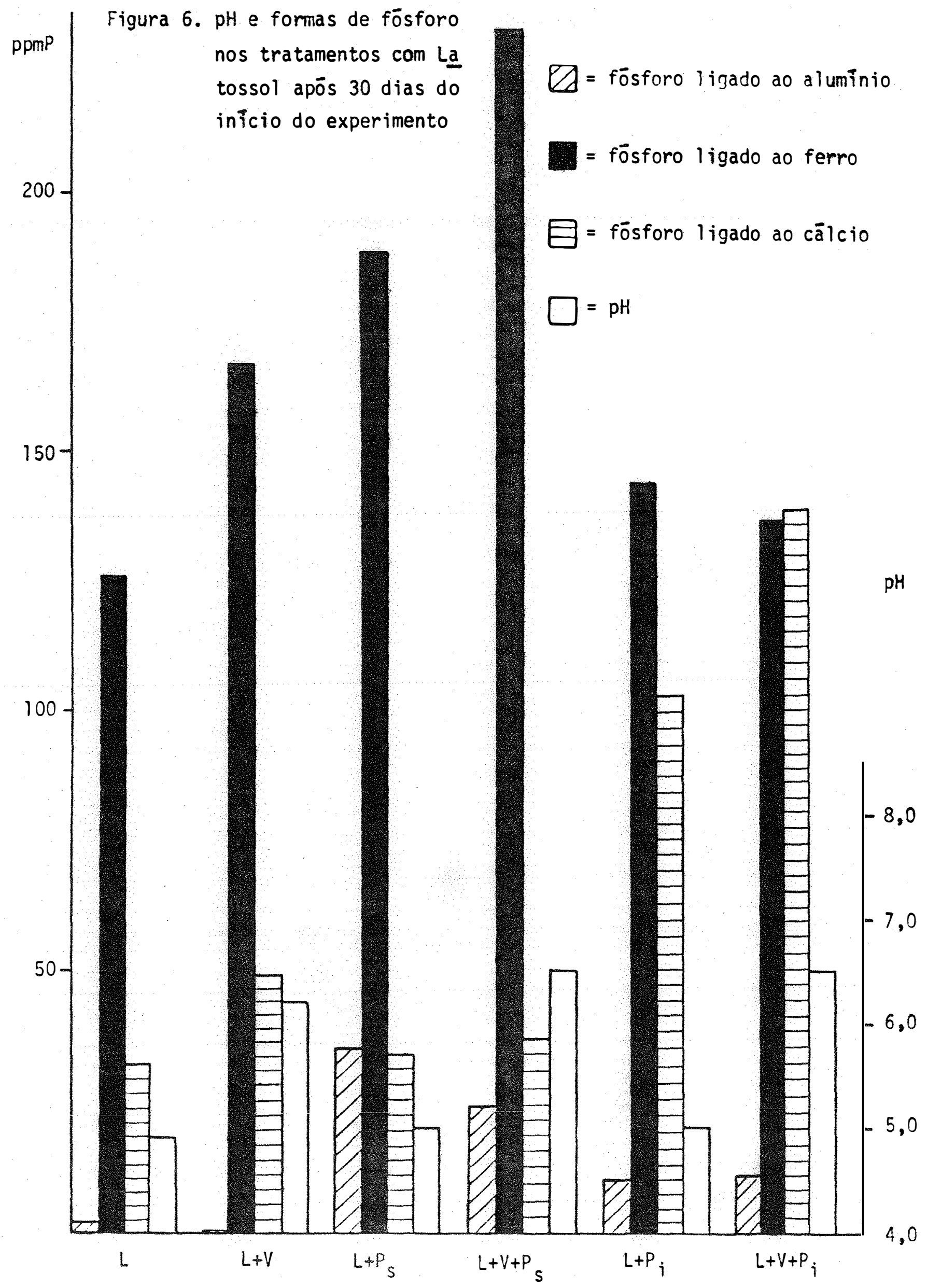


45.

Figura 7. pH e formas de fósforo nos tratamentos com Latossol apōs 60 dias do inicio do experimento

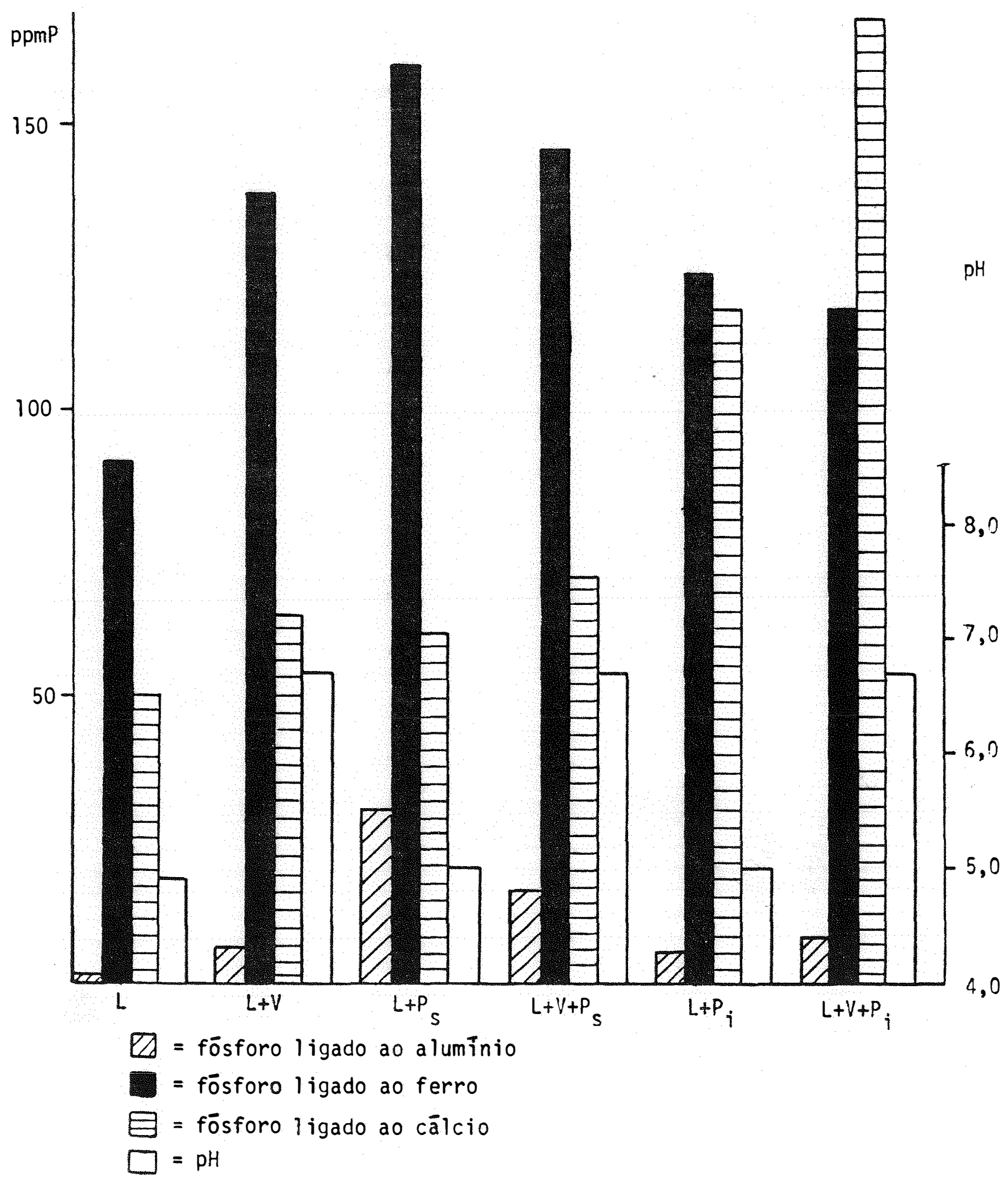


46.

Figura 8. pH e formas de fósforo nos tratamentos com Latossol apōs 91 dias do inicio do experimento

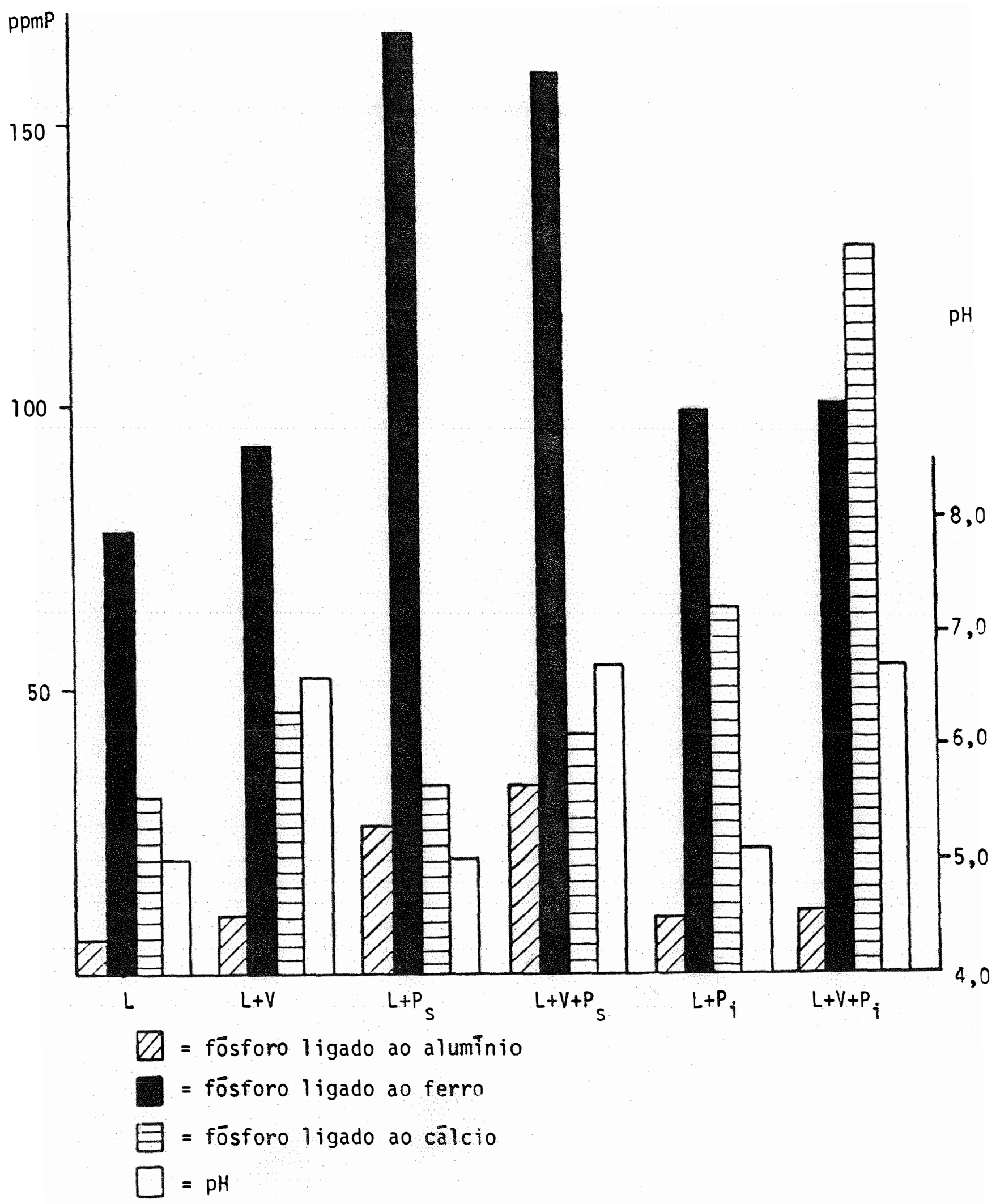


Figura 9. pH e formas de fósforo nos tratamentos com Latossol apōs 122 dias do inicio do experimento

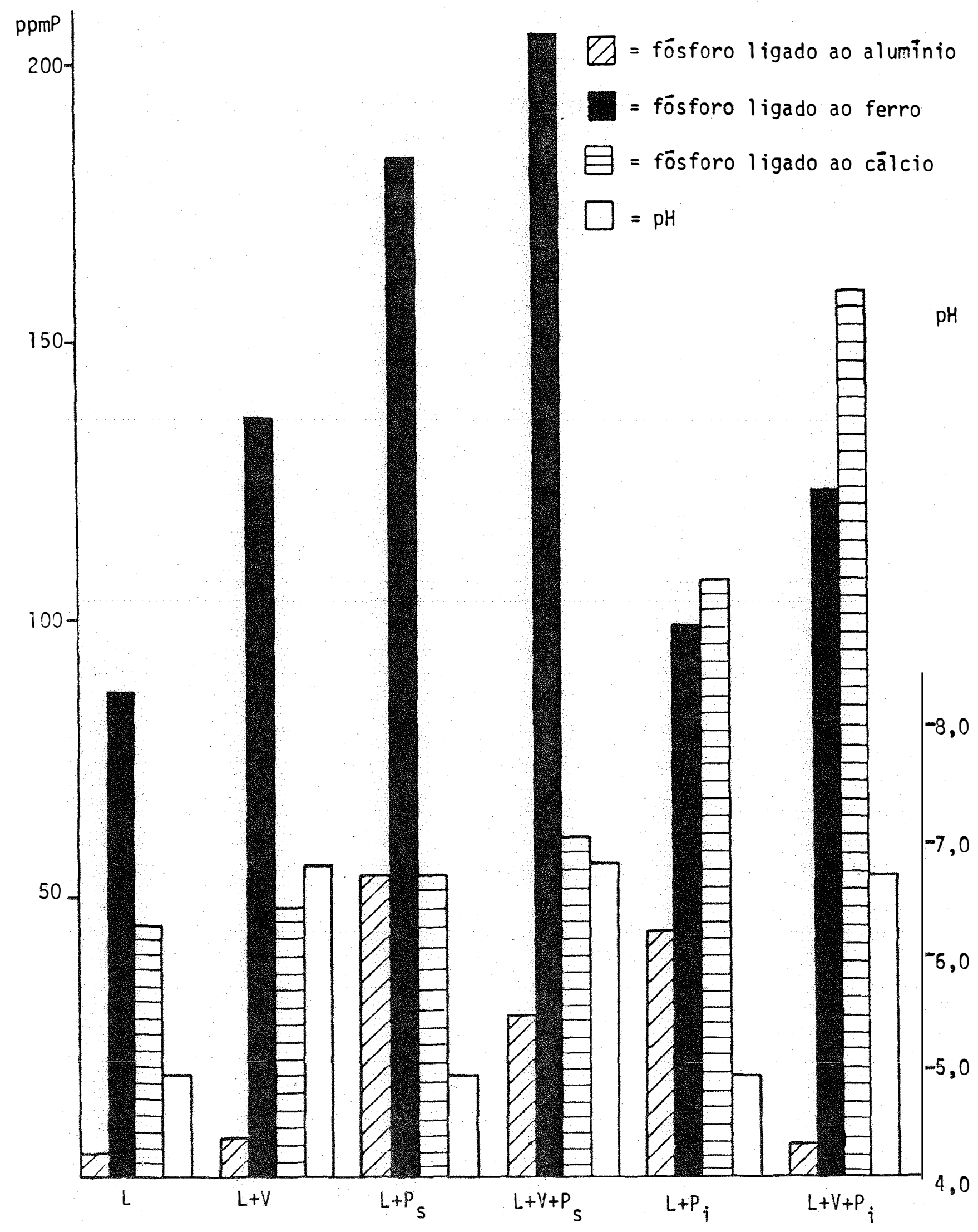


Figura 10. pH e formas de fósforo nos tratamentos com Latossol apōs 183 dias do inicio do experimento

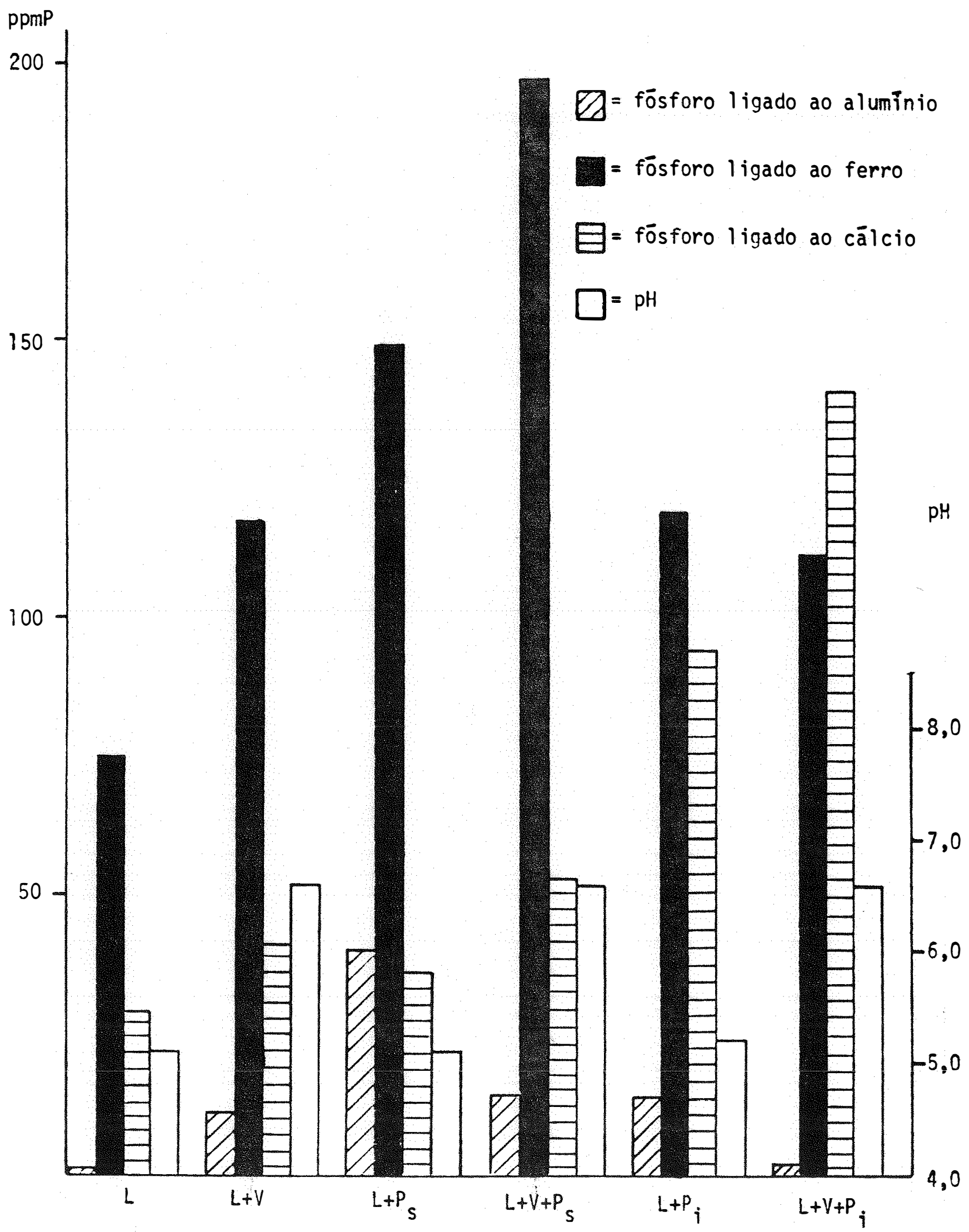


Apesar de existir uma variação acentuada nos nỉveis das värias formas de fósforo no Regossol (R) e no Latossol (L) nas värias amostragens, conforme se verifica pelo exame das figuras, pode-se afirmar que em ambos os solos a fração de fösforo ligada ao ferro é dominante,sen do seguida pelas frações de fósforo ligadas ao cālcio. As formas de fósforo ligadas ao alumīnio são inferiores quando consideradas em relação às duas jā citadas anteriormente.

A adição de vinhaça aos solos provoca elevação no teor de fósforo total dos mesmos, aumento esse proporcionado pelo fósforo proveniente da vinhaça e que se refletiu, principalmente, na elevação do teor de P-Fe. Esse efeito é mais visivel no Latossol que é um solo com alto teor de $\mathrm{Fe}_{2} \mathrm{O}_{3}$ livre.

Nos tratamentos com vinhaça, independente do tipo de solo a forma de fosfato dominante é P-Fe, a seguir vem P-Ca e por ūltimo, num nivel bastante inferior vem $\mathrm{P}-\mathrm{Al}$.

No Regossol a adição de fosfato solūvel provoca aumento nos nỉveis de P-Fe e P-AT, permanecendo o teor de P-Ca no mesmo nível apresentado pelo tratamento testemunha. 0 aumento no teor de $\mathrm{P}-\mathrm{Al}, \overline{\mathrm{e}}$ em relação ao tratamento testemunha, muito maior que o aumento verificado no teor de P-Fe. Todavia nesses solos, devido ao maior teor de P-Fe jā exị tente o fósforo se distribuiu nas seguintes frações em ordem decrescente $\mathrm{P}-\mathrm{Fe}>\mathrm{P}-\mathrm{Al}>\mathrm{P}-\mathrm{Ca}$. A adição conjunta de vinhaça mais fosfato solūvel ao Regossol não modifica as transformações que ocorrem com o fosfato solüvel. 
No Latossol a adição de fosfato solūvel provoca uma elevação acentuada no teor de $\mathrm{P}-\mathrm{Fe}, \mathrm{O}$ que é de se esperar devido ao alto teor de $\mathrm{Fe}_{2} \mathrm{O}_{3}$ livre nele presente. Pode-se observar tambēm 0 aumento no teor de $\mathrm{P}-\mathrm{Al}$, porém esse aumento é relativamente pequeno quando comparado com o verificado para o P-Fe. O nivel de $\mathrm{P}$-Ca permaneceu o mesmo do solo testemunha. Nesse tratamento (Latossol mais fosfato solūvel) o fósforo se distribuiu atē os 90 dias nas seguintes fraçōes em ordem decrescente $\mathrm{P}-\mathrm{Fe}>\mathrm{P}-\mathrm{Ca}>\mathrm{P}-\mathrm{Al}$. Apōs 122 dias houve inversão entre as frações $\mathrm{P}-\mathrm{Ca} e$ $\mathrm{P}-\mathrm{Al}$ ficando a distribuição da seguinte forma $\mathrm{P}-\mathrm{Fe}>\mathrm{P}-\mathrm{Al}>\mathrm{P}-\mathrm{Ca}, \mathrm{O}$ que vem em apoio à teoria de que formas mais solūveis de fósforo como è o caso do P-Ca transformam-se nas formas menos solūveis de $P-A l$ e P-Fe.

A adição conjunta de fosfato solūvel e vinhaça ao Latossol provoca el evação nos seus teores de $\mathrm{P}-\mathrm{Fe}, \mathrm{P}-\mathrm{Ca}$ e $\mathrm{P}-\mathrm{Al}$ sendo $\mathrm{O}$ aumento no teor de P-Fe muito maior do que o verificado para P-Al. Neste tratamento - quadro geral que se apresentou atē os 183 dias de duração do experimento é: a fração $\mathrm{P}-\mathrm{Fe}$ é dominante sobre $\mathrm{P}-\mathrm{Ca}$ e esta sobre $\mathrm{P}-\mathrm{Al}$, podendo-se com isso dizer que no Latossol a aplicação de vinhaça possibilitou que 0 fósforo solúvel adicionado permanecesse mais tempo como fosfato de cālcio.

A adição de fosfato natural (fosfato insolūvel) ao Regossol provocou, inicialmente, uma elevação no teor das tres formas de fósfo ro analisadas ( $\mathrm{P}-\mathrm{Fe}, \mathrm{P}-\mathrm{Ca}$ e $\mathrm{P}-\mathrm{Al})$, sendo que esse aumento è maior no teor das formas de fösforo ligadas ao cālcio conforme jā era esperado, uma vez que o fosfato natural è um fosfato de cālcio. 
Todavia, com o decorrer do tempo, 0 teor de $\mathrm{P}-\mathrm{Ca}$ diminue e aumenta $O$ teor de $\mathrm{P}-\mathrm{Al}$ e $\mathrm{P}-\mathrm{Fe}$ de forma que no final do experimento temse a seguinte distribuição das formas de fósforo: $\mathrm{P}-\mathrm{Fe}>\mathrm{P}-\mathrm{Ca}>\mathrm{P}-\mathrm{Al}$.

No Latossol 30 dias apōs a adição de fosfato natural (fosfato insolūvel) houve aumento nos teores de $\mathrm{P}-\mathrm{Ca}$ e $\mathrm{P}-\mathrm{Fe}$, com $\mathrm{O}$ teor de P-Al praticamente igual à testemunha. Aos 90 dias o teor de cālcio começa a decrescer e o teor de P-Al aumenta atingindo um máximo aos 122 dias e a partir dai o teor de P-Al decresce, aumentando o P-Fe. Nesse tratamento as formas de fósforo estão reunidas na seguinte ordem decrescente $\mathrm{P}-\mathrm{Fe}>\mathrm{P}-\mathrm{Ca}>\mathrm{P}-\mathrm{Al}$.

A adição conjunta de vinhaça mais fosfato natural (fosfato insolúvel) aos dois solos usados no experimento provoca efeitos simila res, traduzido por um aumento no nỉvel de $\mathrm{P}$-Ca $\mathrm{e}$ isso permaneceu até os 183 dias de duração do experimento, isto quer dizer que a adição de vinha ça conserva o fosfato natural adicionado na forma de fosfato de cālcio por um tempo relativamente maior.

A adição de vinhaça ao solo provoca uma ativação da vida microbiana e isso poderā provocar a curto prazo uma imobilização do fósfo ro adicionado, este fato seria traduzido por um aumento no teor de fósforo orgânico do solo (ENWEZOR, 1966).

Todavia, o teor de fósforo orgânico permaneceu praticamente constante em todos os tratamentos no periodo de 30 a 183 dias de duração do experimento (Tabelas $A-1, A-2, A-3, A-4, A-5, A-6, A-7, A-8, A-9$, $A-10, A-11, A-12) \circ$ que pode levar às interpretaçōes: 

dias)

- parte do fósforo orgânico foi extraỉdo juntamente com o fósforo ligado ao ferro na extração III que, segundo CATANI e BATAGLIA (1968) è capaz de extrair parte do fósforo orgânico.

Os Quadros 7 e 8 permitem observar 0 aumento na quantidade de fósforo extraỉdo com $\mathrm{H}_{2} \mathrm{SO}_{4} \quad 0,05 \mathrm{~N}$ nos diversos tratamentos e nos diferentes periodos, aumento esse devido à adição aos solos de materiais contendo fósforo (vinhaça, fosfato solúvel e fosfato insolūvel) e não a um aumento no teor de "fósforo disponīvel"; Observa-se também o maior teor de fósforo nos tratamentos com Regossol evidenciando haver uma maior extração de fósforo neste solo quando comparado com o Latossol, podendo-se com isso dizer que o Regossol retēm o fósforo adicionado com menos firmeza sob forma de P-Al e P-Ca enquanto que $O$ Latossol retém o fósforo adicionado principalmente sob forma de P-Fe e essa forma de fósforo dificilmente è extraĩda pelo $\mathrm{H}_{2} \mathrm{SO}_{4} 0,05 \mathrm{~N}$ (ou não é extraỉda em nỉvel equivalente às demais formas). 
Quadro 7. Teores de fösforo em ppm $P$, extraỉdos com solução $0,05 \mathrm{~N}$ de $\mathrm{H}_{2} \mathrm{SO}_{4}$ nos diferentes tratamentos com Regossol e nos diferentes tempos

\begin{tabular}{crrrrrrr}
\hline Tratamento & 0 & 30 & 60 & 91 & 122 & 151 & 183 \\
\hline 1 & 6 & 7 & 7 & 7 & 7 & 6 & 6 \\
3 & - & 34 & 30 & 30 & 31 & 29 & 31 \\
5 & - & 87 & 93 & 82 & 87 & 90 & 56 \\
7 & - & 119 & 113 & 98 & 107 & 113 & 62 \\
9 & - & 68 & 73 & 50 & 49 & 46 & 35 \\
11 & - & 90 & 85 & 73 & 74 & 71 & 78 \\
\hline
\end{tabular}

Quadro 8. Teores de fósforo, em ppm de $P$, extraỉdos com solução $0,05 \mathrm{~N}$ de $\mathrm{H}_{2} \mathrm{SO}_{4}$, nos diferentes tratamentos com Latossol e nos diferentes tempos

\begin{tabular}{ccrrrrrr}
\hline Tratamento & 0 & 30 & 60 & 91 & 122 & 151 & 183 \\
\hline 2 & 4 & 5 & 5 & 4 & 5 & 4 & 4 \\
4 & - & 17 & 15 & 13 & 12 & 12 & 14 \\
6 & - & 40 & 36 & 37 & 33 & 34 & 37 \\
8 & - & 75 & 75 & 66 & 77 & 74 & 74 \\
10 & - & 36 & 32 & 29 & 26 & 27 & 27 \\
12 & - & 64 & 62 & 62 & 53 & 52 & 55 \\
\hline
\end{tabular}


54.

5. CONCLUSOES

De tudo que foi exposto pode-se concluir que:

- O fosfato solúvel aplicado aos solos tem diferentes destinos conforme o tipo de solo onde ele é aplicado. No Regossol que é um tipo de solo com baixo teor de $\mathrm{Fe}_{2} \mathrm{O}_{3}$ livre o fósforo precipita-se preferencialmente como compostos de aluminnio. No Latossol que é um solo com al to teor de $\mathrm{Fe}_{2} \mathrm{O}_{3}$ livre o fosfato aplicado é encontrado como compostos de fósforo e ferro.

- A adição de vinhaça não modifica as transformações que ocorrem com o fosfato solūvel aplicado ao Regossol, porēm a aplicação conjunta de vinhaça mais fosfato solúvel ao Latossol faz com que o nîvel de fosfatos de cālcio que são as formas mais solúveis de fosfatos sejam mantidos por um tempo mais longo. 
- A adição de fosfato natural (fosfato insolúvel) aos solos do experimento aumentou o nīvel das formas de fósforo ligadas ao cālcio o que é de se esperar devido ao fato do fosfato natural ser um fosfato de cālcio. Com o decorrer do experimento esse fosfato passa para as formas menos solúveis de P-Al e P-Fe, independente do tipo de solo.

- A adição conjunta de vinhaça mais fosfato natural (fosfato insolúvel) aos solos do experimento conserva esse fosfato de cālcio adicionado por mais tempo como tal. 


\section{SUMMARY}

The objective of the present research was to study the behavior of phosphorus in soijs treated with vinasse.

In carrying out the experiment, two different types of soils (Regosol, Sertãozinho series, and Latosol, Iracema series) were used, where, according to the treatment, soluble phosphates, insoluble phosphates, vinasse and water were incorporated. Samples were taken periodically from each treatment and, using methodology proposed by CHANG and JACXSON(1957a), determinations of $\mathrm{pH}$, phosphorus soluble in $0.05 \mathrm{~N}_{2} \mathrm{SO}_{4}$ and the different forms of phosphorus were made.

The results obtained lead to the following conclusions:

- Soluble phosphates added to the soil reacted in different ways, depending on the type of soil where it is applied. In Regosol, a low free $\mathrm{Fe}_{2} \mathrm{O}_{3}$ soil, phosphorus precipitates, mainly in the form of aluminum compounds. In Latosol, a high free $\mathrm{Fe}_{2} \mathrm{O}_{3}$ soil, the applied phosphate is found in the form of phosphorus and iron compounds. 
- The addition of vinasse does not modify the transformations which occur with soluble phosphate applied to Regosol. However, the joint application of vinasse and soluble phosphate to Latosol causes the level of calcium phosphates to remain longer in the soil. This is important because calcium phosphate is the most soluble form of phosphate.

- The addition of insoluble phosphate (natural phosphate) to soils in the experiment increased the level of forms of phosphorus associated with calcium. This was to be expected since the natural phosphate used in the experiment is a calcium phosphate. With the passing of time, this phosphate is transformed into less soluble forms of P-Al and $\mathrm{P}-\mathrm{Fe}$, irrespective of soil type.

- The joint addition of insoluble phosphate (natural phosphate) and vinasse to soils in the experiment maintains this added calcium phosphate as such for a longer period of time. 
58.

7. BIBLIOGRAFIA CITADA

ALEXANDER, M., 1961. Introduction to Soil Microbiology. Hew York, John Wiley, 472 p.

ALMEIDA, J.R., G.RANZANI e 0.VALSECCHI, 1950. La vinasse dans l'agriculture. Boletim do Instituto Zimotēcnico, Piracicaba, no 1, 21 p.

ALMEIDA, J.R., G. RANZANI e 0. VALSECCHI, 1951. L'emploi de la vinasse dans l'agriculture. Boletim do Instituto Zimotécnico, Piracicaba, no 2, $16 \mathrm{p}$.

ALMEIDA, J.R., 1952. O problema da vinhaça em São Paulo. Boletim do Instituto Zimotécnico, Piracicaba, no 3, $24 \mathrm{p}$.

ALMEIDA, F.P., 1953. Interferência dos fungos na adubação do solo pela vị nhaça. Boletim do Instituto Zimotécnico, Piracicaba, nọ 5, 9 p.

ASSOCIAÇAO NACIONAL PARA DIFUSAOO DE ADUBOS, 1978. Setor Fertilizantes; Pro dução e consumo: 1969-1983. São Paulo, 81 p. 
ARAUJO, N.Q., A.S.VISCONTI, H.E.CASTRO, H.G.B.SILVA, M.H.A.FERRAZ e M. SALLES FILHO, 1976. Produção de biomassa füngica de vinhoto. Brasil. Açucareiro, Rio de Janeiro, $\underline{88}(6): 479-489$.

BAHIA FILHO, A.F.C., 1974. Fösforo em Latossolo do Estado de Minas Gerais: intensidade, capacidade tampão, quantidade de fósforo"disponīvel" e cres cimento vegetal. Viçosa, UFV, 69 p. (Dissertação de M.S.)

BAJPAI, P.D. e W.V.B.SUBBA-RAO, 197la. Phosphate solubilizing bacteria. I. Solubilization of phosphate in liquid culture by selected bacteria as affected by different pH values. So il Science and Plant Nutrition, Tokyo, 17:41-43.

BAJPAI, P.D. e W.V.B.SUBBA-RAO, 1971b. Phosphate solubilizing bacteria. III. Soil inoculation with phosphorus solubilizing bactēria. Soil Science and Plant Nutrition, Tokyo, 17:46-53.

BARBER, D.A., 1968. Effects of microorganisms on the absorption of inorganic nutrients by plants. In: Symposium on the Use of Isotopes and Radiation in Soil Organic-Matter Studies, Vienna, IAEA, p.365-375.

BARBER, D.A. e B.C.LOUGHMAN, 1967. The effect of microorganisms on the absorption of inorganic nutrients by intact plants. II. Uptake and utilization of phosphate by barley plants grown under sterile and nonsterile conditions. Journal of Experimental Botany, 0xford, 18:170176.

BEAR, F.E., 1964. Chemistry of the Soil. 2.ed. New York, Reinhold, $515 p$. 
BIRCH, H.F., 1961. Phosphorus transformations during plant decomposition. Plant and Soil, The Hague, 15(4):347-366.

BITTENCOURT, V.C. e E.ZAMBELLO JUNIOR, 1973. Comportamento do fösforo em solos tropicais. I. Isotermas de adsorção. Boletim Científico do Centro de Energia Nuclear na Agricultura, Piracicaba, no 12, 23 p.

BITTENCOURT, V.C. e M.N.S.MONTANHEIRO, 1975. Retenção do fösforo $\left({ }^{32} \mathrm{P}\right)$ por óxidos de ferro sintéticos. Boletim Cientifico do Centro de Energia. Nuclear na Agricultura, Piracicaba, nọ 26, 18 p.

BITTENCOURT, V.C. e V.B.GOMES, 1975. Avaliação da disponibilidade de P de fosfatos de ferro e de aluminio. Boletim Científico do Centro de Energia Nuclear na Agricultura, Piracicaba, no 35, 18 p.

BITTENCOURT, V.C., J.ORLANDO FILHO e E.ZAMBELLO JUNIOR, 1977. Determination of available $P$ for sugarcane in tropical soils extracted with $\mathrm{H}_{2} \mathrm{SO}_{4} 0,5 \mathrm{~N}$. In: Proceedings of the XVI Congress International Society of Sugar Cane Technologists, São Paulo, v. 2, p. 1175-1186.

BLACK, A.L. e L.L. REITH, 1972. Phosphorus and nitrate nitrogen immobilization by wheat straw. Agronomy Journal, Washington, 64:782-735.

BORNEMISZA, E., 1966. Organic phosphorus in tropical soils. Turrialba, 16: $33-38$.

BORNEMISZA, E. e K. IGUE, 1967. Comparison of three methods for determining organic phosphorus in Costa Rica Soils. Soil Science, New Brunswick, $103: 347-353$. 
BORNEMISZA, E., L.S.VIEIRA, e K. IGUE, 1967. The method of MEHTA et al modified for determination of organic phosphorus in soils high extractable iron. Proceedings of the Soil Science Society of America, Madison, $31: 576-577$.

BREMNER, J.M., 1956. Some Soil organic matter problems soils and Fertilizers, Farnham Royal, 29(2):115-123.

BUCKMAN, H.O. e N.C.BRADY, 1968. Natureza e Propriedade dos Solos. 2.ed. São Paulo, Livraria Freitas Bastos, 594 p.

CAMARGO, R., 1954. O desenvolvimento da flora microbiana nos solos tratados com vinhaça. Boletim do Instituto Zimotécnico, Piracicaba, nọ 9, 44 p.

CARVALHO, P.C.T., A.F.da EIRA e D.PELLEGRINO, 1969. Solubilização quantitativa de fosfatos insolūveis por algumas espēcies dos gêneros Aspergillus e Penicillium. Anais da Escola Superior de Agricultura "Luiz de Queiroz", Piracicaba, 26: 173-185.

CATANI, R.A. e D.PELLEGRINO, 1960. Avaliação da capacidade de fixação de fósforo pelo solo. Anais da Escola Superior de Agricultura "Luiz de Queiroz", Piracicaba, 17:20-27.

CATANI, R.A. e N.A.da GLORIA, 1964. Evaluation of the capacity of phosphorus fixation by the soil through the isotopic exchange using $P^{32}$. Anais da Escola Superior de Agricultura "Luiz de Queiroz", Piracicaba, 21:230237. 
CATANI, R.A. e O.C.BATAGLIA, 1968. Formas de ocorrência do fósforo no so10 latossōlico roxo. Anais da Escola Superior de Agricultura "Luiz de. Queiroz", Piracicaba, 25:99-119.

CATANI, R.A., 1969. A fixação do fósforo por alguns solos do Brasil e a adubação fosfatada. Revista Agronômica, Lisboa, 52:83-87.

CATANI, R.A. e A.0.JACINTHO, 1974. Avaliação da Fertilidade do Solo; Métodos de anālise. Piracicaba, Livro-Ceres, $61 \mathrm{p}$.

CAVALCANTI, F.J.A., 1974. Alguns aspectos da fixação do fösforo por solos da região de Piracicaba. Piracicaba, ESALQ/USP, 62 p. (Dissertação de mestrado).

CHANG, S.C. e M.L.JACKSON, 1957a. Fractionation of soil phosphorus. Soil Science, New Brunswick, 84,133-144.

CHANG, S.C. e M.L.JACKSON, 1957b. Solubility product of iron phosphate. Proceedings of Soil Science Society of America, Madison, 21:265-269.

CHANG, S.C. e M.L.JACKSON, 1958. Soil phosphorus in some representative soils. Journal of Soil Science, Oxford, 9:109-119.

CHANG, S.C. e W.K.CHU, 1961. The fate of soluble phosphate applied to soils. Journal of Soil Science, Oxford, 12:286-293.

CHANG, S.C. e F.W.LIAW, 1962. Separation of aluminum phosphate from iron in soils. Science, Washington, 136:386. 
63.

CHANG, S.C. e S.R.JUO, 1963. Avaiable phosphorus in relation to forms of phosphates in soils. Soil Science, New Brunswick, 95:91-95.

DALTON, J.D., G.C.RUSSEL, D.H.SIELING, 1952. Effect of organic matter on phosphate availability. Soil Science, New Brunswick, 73:173-181.

DOMMERGUES, Y. e F.MANGENOT, 1970. Ecologie Microbienne du Sol. Paris, Masson, $796 \mathrm{p}$.

EIRA, F.A. e P.C.T.CARVALHO, 1968. Levantamento de microrganismos solubilizadores de fosfatos. In: XX Reunião Anual da Sociedade Brasileira pa ra o Progresso da Ciência, São Paulo, USP, p. 266-267.

EIRA, F.A. e P.C.T.CARVALHO, 1970. A decomposição da matéria orgânica pelos microorganismos do solo e sua influência nas variações de pH. Revista da Agricultura, Piracicaba, 45:15-21.

ENWEZOR, W.0., 1966. The biological transformation of phosphorus during the incubation of a soil treated with soluble inorganic phosphorus and with fresh and rotted organic materials. Plant and Soil, The Hague, 25: 463-466.

ENWEZOR, W.0., 1976. The mineralization of nitrogen and phosphorus in organic materials of varying C:N e C:P ratios. Plant and Soil, The Hague, $44: 237-240$.

ENWEZOR, W.O., 1977. Soil testing for phosphorus in some nigerian soils. III. Forms of phosphorus in soils of Southeastern Nigeria and their relationship to plant available phosphorus. Soil Science, New Brunswick, 124:27-33. 
FARES, F., J.C.FARDEAU e F.JACQUIN, 1974. Quantitative survey of organic phosphorus in different soil types. Phosphorus in Agriculture, London, $63: 25-40$.

FERREIRA, M.E., 1973. Estudos sōbre a fixação de fosfato nos latossolos roxo e vermelho escuro, fase arenosa de Jaboticabal. Jaboticabal, S.P., FMVAJ, 165 p. (Tese de doutoramento).

FIFE, C.V., 1962. An evaluation of amonium fluoride as a selective extractant for aluminum-bound soil phosphate. III. Detailed studies on selected soils. Soil Science, New Brunswick, 93:113-126.

FIFE, C.V., 1963. An evaluation of amonium fluoride as a selective extractant for aluminum-bound soil phosphate. IV. Detailed studies on soils (2). Soil Science, New Brunswick, 96:111-120.

GLORIA, N.A. da, A.G.SANTA ANA e H.MONTEIRO, 1972. Composição dos resīduos de usinas de açūcar e destilarias de ālcool durante a safra canavieira. Brasil Açucareiro, Rio de Janeiro, 80(5):542-548.

GLORIA, N.A.da, A.G.SANTA ANA e E.BIAGI, 1973. Composição dos resĩduos de usinas de açücar e destilarias. Brasil Açucareiro, Rio de Janeiro, 81 (6) :78-87.

GLORIA, N.A.da, 1975. Utilização agrīcola da vinhaça. Brasil Açucareiro, Rio de Janeiro, 86:397-403.

GLORIA, N.A.da, 1976. Emprego da Vinhaça para Fertilização. Piracicaba, Codistil, n.p. 
65.

GLÖRIA, N.A.da, D.PELLEGRINO e M.E.MATTIAZZO, 1976. Efeito da ma tēria orgânica na solubilização de fosfatos no solo. I- Efeito da torta de mamona. Revista da Agricultura, Piracicaba, 51 (3/4):253-261.

GLÖRIA, N.A.da e J.A.MAGRO, 1976. Utilização agrīcola de resỉduos de usinas de açücar e destilarias na Usina da Pedra. In: Anais do IV Seminārio COPERSUCAR da Agro-Indūstria Açucareira, Aguas de Lindoia, S.P., Co persucar, S.P., p. 163-180.

GLORIA, N.A.da e M.E.MATTIAZZO, 1976a. Efeito da matēria orgânica na solú bilização de fosfatos no solo. II- Efeito de residuos de usinas de açúcar e destilarias (bagaço de cana, torta de filtro e vinhaça). Brasil Açucareiro, Rio de Janeiro, $\underline{88}(5): 386-395$.

GLORIA, N.A.da e M.E.MATTIAZZO, 1976b. Efeito da matēria orgânica na solubilização de fosfatos no solo. III- Efeito de resĩduos de destilarias (vinhaça). Brasil Açucareiro, Rio de Janeiro, 45:55-52.

GLORIA, N.A.da, 1977a. Aproveitamento de resỉduos agro-industriais: palestra. Piracicaba, ESALQ/USP, 9 p. (Curso de pōs-graduação em economia agrāria).

GLORIA, N.A.da, 1977b. Fösforo no solo: Aula. Piracicaba, ESALQ/USP, 15 p. (Curso de pōs-graduação em Solos e Nutrição de Plantas).

GLORIA, N.A.da, 1977c. Uso de resíduos de destilação na agricultura: Palestra. In: 20 Simpōsio de Fermentação Alcoōlica, Piracicaba, ESALQ, $11 \mathrm{p}$. 
GONÇALVES, J.A.T.D., 1977. Indústria de Fertilizantes; Presente e Futuro. In: I Semana de Fertilizantes, Piracicaba, Centro Acadêmico "Luiz de Queiroz", $32 \mathrm{p}$.

GRACIO, J.T.M. e N.O.LIMA, 1962. Phosphorus fixation in acid soils. IIThe effect of chelates, lime and silicates on phosphorus fixation. Agronomia Lusitana, Oeiras, 24:289-300.

GRAY, L.E. E J.W. GERDEMANN, 1969. Uptake of phosphorus $\left({ }^{32} \mathrm{p}\right)$ by vesicular arbuscular mycorrhizal. Plant and Soil, The Hague, 38:415-422.

GREB, B.W. e S.R.OLSEN, 1967. Organic phosphorus in calcareous Colorado soils. Proceedings of Soil Science Society of America, Madison, 31: 85-89.

HALSTEAD, R.L., 1963. Phosphatase activity of soils as influenced by lime and other treatments Canadian Journal of Soil Science, Ottawa, $44: 137-144$.

HANNAPEL, R.J., W.H.FULLER e R.H.FOX, 1964. Phosphorus movement in a calcareous soil. II-Soil microbial activity and organic phosphorus movement. Soil Science, New Brunswick, 97:421-427.

HENDERSON, G.S. E E.L.STONE JR., 1970. Interaction phosphorus availability, mycorrhizal and soil fumigation on coniferous seedling. Proceedings of Soil Science Society of America, Madison, 34:314-318.

HSU, P.H. e M.L.JACKSON, 1960. Inorganic phosphate transformation by chemical weathering in soils as influenced by $\mathrm{pH}$. Soil Science, New Brunswick, 90:16-24. 
HSU, P.H., 1964. Adsorption of phosphate by aluminum and iron in soils. Proceedings of Soil Science Society of America, Madison, 28:474-478.

HSU, P.H., 1965. Fixation of phosphate by aluminum and iron in acid soils. Soil Science, New Brunswick, 99:398-402.

IPINMIDUM, W.B., 1973. Comparison of some methods for determining organic phosphorus in some nigerian soils. Soil Science, New Brunswick, 115: 324-325.

JACKSON, N.E., R.E.FRANKLIN e R.H.MILLER, 1972. Effect of vesicular arbuscular mycorrhizal on growth and phosphorus content of three agronomic crops. Proceedings of Soil Science Society of America, Madison, 36:6467.

JELNIC, D. e M.HAJDUKOVIC, 1965. Influence of organic matter on the solubility of calcium phosphates in soil. In: Symposium on Isotopes and Radiation in Soil Plant Nutrition Studies, Ankara, FAO/IAEA, p. 35-36.

JORGE, J.A. e J.VALADARES, 1969. Formas de fósforo em solos do Estado de São Paulo. Bragantia, Campinas, 28(2):23-30.

JORGE, J.A., 1972. Matēria orgânica. In: MONIZ, A.C., coord. Elementos. de Pedologia. São Paulo, Polígono, p. 169-177.

KAILA, A., 1949. Biological absorption of phosphorus. Soil Science. New Brunswick, 68:279-289. 
LAI, T.M. e E.OKAZAKI, 1970. Phosphorus availability influenced by ānions, microorganisms and organic matter. Report Hawaiian Sugar Planters' AsSociation Experiment Station, Honolulu, p. 50-52.

LARSEN, S., 1968. The influence of soil organic matter on loss of available phosphate in soil by chemical reactions. In: Symposium on the Use of Isotopes and Radiation in soil organic-matter studies, Vienna, IAEA, p. 377-383.

LAVERTY, J.C. e E.O.MCLEAN, 1961. Factors affecting yield and uptake of phosphorus by differente crops. III. Kinds of phosphate, native applied and formed. Soil Science, New Brunswick, 91:166-171.

MALAVOLTA, E. e D.PELLEGRINO, 1954. Nota sôbre al gumas transformações do superfosfato radioativo em terra roxa. Revista da Agricultura, Piracicaba, 29:317-323.

MALAVOLTA, E., 1967. Manual de Quỉmica Agrīcola; adubos e adubação. 2a ed. São Paulo, Editora Agronômica Ceres, 606 p.

MALAVOLTA, E, ,1976. Manual de Quỉmica Agricola; Mutrição de Plantas e Fer tilidade do Solo. São Paulo, Editora Agronômica Ceres, 528 p.

MEJSTRIK, V., 1970. The uptake of ${ }^{32} \mathrm{p}$ by different kinds of ectotrophic mycorrhizal of Pinus. New Phytologist, Cambridge, 69:295-298.

MOREAU, R., 1959. The biological liberation of soluble phosphates from insoluble phosphorus compounds in soil. Comptes Rendus Hebdomadaires des Séances de l'Académie des Sciences, Paris, 249:1804-1806. 
NISHITA, H., R.M.HAUG e G.V.ALEXANDER, 1973. Influence of organic matter on the availability of certain elements to barley seedlings grown by a modified Neubauer method. Plant and Soil, The Hague, 39:161-176.

OTHIENO, C.0., 1973. The effect of organic mulches on yields and phosphorus utilization by plants in acid soils. Plant and Soil, The Hague, 38: $17-32$.

PASQUAL, A., 1973. Efeito de doses elevadas de fōsforo na produção do miTho (Zea mays L.) e nas principais formas de ocorrência desse elemento em dois solos do Estado de São Paulo. Botucatu, FCMBB, 73 p. (Tese de doutoramento).

PATEL, J.M. e B.V.MEHTA, 1961. Soil phosphorus fractionation studies. Proceedings of the Soil Science Society of America, Madison, 25:190-192.

PHILLIPS, A.B. e J.R.WEBB, 1973. Production, marketing and use of phosphorus fertilizers. In: OLSON, R.A., T.J.ARMY, J.J.HANWAY e V.J.KILMER. Fertilizers Tecnology and Use. 2.ed. Madison, Soil Science Society of America, p. 271-301.

PINTO, R., 1974. Forms of phosphate and their availability to plants. Tropical Agriculture, London, 51:179-188.

POCHON, J. e H.BARJAC, 1958. Phosphore. In: POCHON, J. e H.BARJAC. Traitē de microbiologie des sols. 6.ed. Paris, Dunod, p. 303-314.

PONTES, J.F., 1959. A "calda" e seus principais elementos minerais. Brasil Açucareiro, Rio de Janeiro, 53:11-15. 
PRATT, P.F., 1966. Quỉmica do Solo. Trad. de A.Nascimento e L.Vettori. Rio de Janeiro, USAID/Brasil, $87 \mathrm{p}$.

RAMOS, A., V.CALLAO e P.C.T.CARVALHO, 1968. La solubilizaciōn de fosfatos por hongos del suelo. Microbiologia española, Madrid, 21:23.

RANZANI, G., O.fReIRE e T.KINJO, 1966. Carta de Solos do Municipio de Piracicaba. Piracicaba, Centro de Estudos de Solos, ESALQ, 61 p.

RODELLA, A.A. e S.E.FERRARI, 1977. A composição da vinhaça e efeitos da sua aplicação como fertilizante na cana-de-açūcar. Brasil Açucareiro, Rio de Janeiro, 90:380-387.

ROSS, V.P. 1971. Effect of phosphate fertilization on yield of mycorrhizal and nonmycorrhizal soybeans. Phytopathology, Lancaster, 61(11):14001403.

ROSS, J.P. e J.W.GILLIAM, 1973. Effect of endogone mycorrhizal on phosphorus uptake by soybeans from inorganic phosphates. Proceedings of the Soil Science Society of America, Madison, 37(2):237-239.

SAUDERS, W.M.H. e E.G.WILLIAMS, 1955. Observation on the determination of total organic phosphorus in soils. Journal of Soil Science, Oxford, $\underline{6}$ : $254-267$.

SHAPIRO, R.E., 1958. Effect of organic matter and flooding on availability of soil and sinthetic phosphates. Soil Science, New Brunswick, 85:267272. 
SHERMAN, G.D., 1971. Phosphorus availability in tropical soils. Agri Digest, Brussels, 23:12-22.

SINHA, M.R., 1972. Organo-metallic phosphates. IV. The solvent action of fulvic acids on insolubles phosphates. Plant and Soil, The Hague, 37: 457-467.

SMITH, A.N., 1969. Fractionation of inorganic phosphorus in soils. The Chang and Jackson fractionation procedure: its limitation and use. Agri Digest, Brussels, 17:10-19.

STANFORD, G. e W.H.PIERRE, 1953. Soil management practices in relation to phusphorus availability and use. In:PIERRE, W.H. e A.G.NORMAN. Soil and Fertilizer Phosphorus in crop nutrition. New York, Academic press, p. 247-251. (Agronomy, v. 4).

STANIER, R.Y., M.DOUDOROFF e E.A.ADELBERG, 1969. Nutrição e fisiologia microbiana. In: STANIER, R.Y. et alii. Mundo dos Micrōbios. São Pau10, Edgard Blucher, p. 277-297.

STREL'CHENKO, N.YE., 1973. Phosphate forms and their distribution in the profile of soils in Primorskiy Kray. Soviet Soil Science, Madison, 5: 582-589.

SUBBA-RAO, N.S. E P.D.BAJPAI, 1965. Fungi on the surface of legume root nodules and phosphate solubilization. Experientia, Basel, 21:386-387. Apud Soils and Fertilizers, 29:1113,1966. 
TISDALE, S.L. e W.L.NELSOH, 1966. Soil and fertilizer phosphorus. In: TISDALE, S.L. e W.L.NELSON. Soil Fertility and Fertilizers. 2.ed. New York, MacMillan p. 194-251.

THOMPSON, L.M., C.A.BLACK e J.A.ZOELNNER, 1954. Ocurrence and mineralization of organic phosphorus in soils with particular reference to association with nitrogen, carbon and pH. Soil Science, New Brunswick, 77: 185-196.

VALSECCHI, 0. e F.PIMENTEL GOMES, 1954. Solos incorporados com vinhaça e seu teor em bases. Anais da Escola Superior de Agricultura "Luiz de Queiroz", Piracicaba, 11:136-158.

VALSECC:1I, 0., 1955. Alguns aspectos do problema da vinhaça. Brasil Açucareiro, Rio de Janeiro, 46:57-62.

VAil DIEST, A., 1968a. Biological immobilization of fertilizer phosphorus. I. Accumulation of soil organic phosphorus in coastal plains of New Jersey. Plant and Soil, The Hague, 29:241-247.

VAN DIEST, A., 1968b. Biological immobilization of fertilizer phosphorus. II. Evaluation of factors involved in phosphorus transformation. Plant. and Soil, The Hague, 29:248-256.

VAN RAIJ, B., 1969. A capacidade de troca de cátions das frações orgânica e mineral em solos. Bragantia, Campinas, 28:85-112.

VERDADE, F.C., 1956. Influência da matéria orgânica na capacidade de troca de cátions pelo solo. Bragantia, Campinas, 15:35-42. 
VOLK, V.V., E.O.MCLEAN, 1963. The fate of applied phosphorus in four Ohio soils. Proceedings of the Soil Science Society of America, Madison, 27:53-58.

YUAN, T.L., W.K.ROBERTSON E S.R.MELLER, 1960. Forms of newly fixed phosphorus in three acid sandy soils. Proceedings of the Soil Science Society of America, Madison, 24:447-450.

WAKSMAN, S.A., 1952. So il microbiology. New York, John Wiley, 356 p.

WILLIAMS, J.D.H., J.K.SYERS e T.W.WALKER, 1967. Fractionation of inorganic phosphate by a modification of Chang e Jackson's procedure. Proceedings, of the Soil Science Society of America, Madison, 31:736-739.

WUTKE, A.C.P. e 0.A.CAMARGO, 1972. Adsorção e troca iōnica. In: MONIZ, A. C., coord. Elementos de Pedologia. São Paulo, Polígono, p.125-147.

ZAK, G.A. e M.F.MUKHUTDINOV, 1964. Effectiveness of bacterial fertilizers for vegetables. Izv. Kuibyshev Sol: Khoz. Inst., 14:80-88. Apud Soils, and Fertilizers, 29:345, 1966.

ZAREMBA, V.P., E.G.TOMASHEVSKAYA e S.M.MALINSKAYA, 1966. Ability of nodule bacteria to utilize difficulty soluble phosphates of calcium. Sel Khoz. Biol., 1:842-850. Apud Soils and Fertilizers, 30:1944, 1967. 
$A P E N D I C E$ 
Tabela A-1. Formas de fósforo em ppm de $P$ no tratamento 1 (Regossol) nos diferentes tempos

\begin{tabular}{|c|c|c|c|c|c|c|}
\hline \multirow{2}{*}{$\begin{array}{l}\text { Formas de } \\
\text { fösforo }\end{array}$} & \multicolumn{6}{|c|}{ Tempo (dias) } \\
\hline & 30 & 60 & 91 & 122 & 151 & 183 \\
\hline$P$ - solūvel & $<1$ & $<1$ & $<1$ & $<1$ & - & $<1$ \\
\hline$P$ - aluminnio & 4 & 7 & 4 & 9 & - & 9 \\
\hline$P$ - ferro & 46 & 36 & 48 & 34 & - & 36 \\
\hline P-cálcio & 11 & 8 & 11 & 14 & - & 14 \\
\hline P - orgânico & 67 & 90 & 64 & 71 & 86 & 75 \\
\hline$P$ - total & 163 & 181 & 167 & 156 & 173 & 155 \\
\hline
\end{tabular}


Tabela A-2. Formas de fósforo em ppm $P$ no tratamento 3 (Regossol + vinhaça) nos diferentes tempos

\begin{tabular}{lcccccc}
\hline \multirow{2}{*}{$\begin{array}{c}\text { Formas de } \\
\text { fósforo }\end{array}$} & 30 & 60 & 91 & 122 & 151 & 183 \\
\cline { 2 - 6 } & $<1$ & 3 & $<1$ & 3 & - & 3 \\
\hline - solüvel & 5 & 9 & 8 & 7 & - & 12 \\
$P-$ aluminio & 82 & 50 & 60 & 78 & - & 63 \\
$P-$ ferro & 18 & 11 & 21 & 28 & - & 17 \\
$P-$ călcio & 75 & 88 & 62 & 58 & 75 & 62 \\
$P$ - orgânico & 199 & 228 & 213 & 216 & 220 & 199 \\
$P-$ total & & & & & & \\
\hline
\end{tabular}


76.

Tabela A-3. Formas de fösforo em ppm $P$ no tratamento 5 (Regossol $+v i-$ nhaça + fosfato solūvel) nos diferentes tempos

\begin{tabular}{lcccccc}
\hline Formas de & \multicolumn{6}{c}{ Tempo (dias) } \\
fósforo & 30 & 60 & 91 & 122 & 151 & 183 \\
\cline { 2 - 7 } & 2 & 12 & 11 & 11 & - & 13 \\
$P$ - solūvel & 37 & 48 & 31 & 43 & - & 40 \\
$P$ - aluminio & 128 & 108 & 116 & 135 & - & 138 \\
$P$ - ferro & 14 & 15 & 23 & 35 & - & 30 \\
$P$ - cālcio & 90 & 87 & 53 & 43 & 71 & 49 \\
$P$ - orgànico & 327 & 338 & 321 & 343 & 340 & 280 \\
$P$ - total & & & & & & \\
\hline
\end{tabular}


Tabela A-4. Formas de fösforo em ppm P no tratamento 7 (Regossol + vinhaça + fosfato insolüvel) nos diferentes tempos

\begin{tabular}{lcccccc}
\hline Formas de & \multicolumn{6}{c}{ Tempo (dias) } \\
\cline { 2 - 6 } fösforo & 30 & 60 & 91 & 122 & 151 & 183 \\
\hline$P$ - solūivel & $<1$ & 3 & 2 & 3 & - & 3 \\
$P$ - aluminio & 7 & 13 & 12 & 15 & - & 16 \\
$P$ - ferro & 79 & 55 & 70 & 71 & - & 56 \\
$P$ - cālcio & 127 & 113 & 116 & 131 & - & 114 \\
$P$ - orgânico & 80 & 86 & 68 & 55 & 68 & 53 \\
$P$ - total & 296 & 332 & 307 & 352 & 335 & 299 \\
\hline
\end{tabular}


Tabela A-5. Formas de fósforo em ppm P, no tratamento 9 (Regossol + fosfato solūvel) nos diferentes tempos

\begin{tabular}{|c|c|c|c|c|c|c|}
\hline \multirow{2}{*}{$\begin{array}{l}\text { Formas de } \\
\text { fösforo }\end{array}$} & \multicolumn{6}{|c|}{ Tempo (dias) } \\
\hline & 30 & 60 & 91 & 122 & 151 & 183 \\
\hline P - solūvel & 14 & 10 & 6 & 8 & - & 6 \\
\hline$P$ - aluminio & 65 & 109 & 62 & 94 & - & 74 \\
\hline$P$ - ferro & 96 & 82 & 76 & 95 & - & 86 \\
\hline P - cālcio & 12 & 10 & 16 & 20 & - & 14 \\
\hline$P$ - orgānico & 63 & 56 & 61 & 63 & 63 & 76 \\
\hline$P$ - total & 296 & 332 & 264 & 270 & 273 & 250 \\
\hline
\end{tabular}


79.

Tabela A-6. Formas de fósforo em Ppm P, no tratamento 11 (Regossol + fosfato insolūvel) nos diversos tempos

\begin{tabular}{lcccccc}
\hline $\begin{array}{c}\text { Formas de } \\
\text { fósforo }\end{array}$ & 30 & 60 & 91 & 122 & 151 & 183 \\
\cline { 2 - 6 } & 3 & $<1$ & 2 & 4 & - & 3 \\
$P-$ solūvel & 14 & 23 & 34 & 66 & - & 46 \\
$P-$ aluminio & 77 & 52 & 64 & 53 & - & 71 \\
$P-$ ferro & 79 & 67 & 76 & 63 & - & 56 \\
$P$ - cāicio & 87 & 69 & 72 & 64 & 80 & 64 \\
$P$ - orgânico & 304 & 280 & 254 & 280 & 275 & 270 \\
$P$ - total & & & & & & \\
\hline
\end{tabular}


Tabela A-7. Formas de fösforo em ppm $P$, no tratamento 2 (Latossol) nos diversos tempos

\begin{tabular}{lcccccc}
\hline Formas de & \multicolumn{5}{c}{ Tempo (dias) } \\
\cline { 2 - 6 } fósforo & 30 & 60 & 91 & 122 & 151 & 183 \\
\hline$P$ - solūvel & $<1$ & $<1$ & $<1$ & $<1$ & - & $<1$ \\
$P$ - aluminio & 2 & 6 & 1 & 4 & - & 1 \\
$P$ - ferro & 126 & 78 & 91 & 87 & - & 75 \\
$P$ - cálcio & 32 & 31 & 50 & 45 & - & 29 \\
$P$ - orgànico & 296 & 288 & 300 & 309 & 307 & 327 \\
$P$ - total & 833 & 981 & 968 & 952 & 933 & 870 \\
\hline
\end{tabular}


Tabela A-8. Formas de fösforo em ppm P, no tratamento 4 (Latossol + vi nhaça) nos diferentes tempos

\begin{tabular}{lcccccc}
\hline $\begin{array}{c}\text { Formas de } \\
\text { fósforo }\end{array}$ & 30 & 60 & 91 & 122 & 151 & 183 \\
\cline { 2 - 6 } & $<1$ & $<1$ & $<1$ & $<1$ & - & $<1$ \\
$P$ - solüvel & $<1$ & 10 & 6 & 7 & - & 11 \\
$P$ - aluminio & 167 & 93 & 138 & 136 & - & 117 \\
$P$ - ferro & 49 & 46 & 64 & 48 & - & 41 \\
$P$ - cālcio & 254 & 384 & 278 & 291 & 252 & 289 \\
$P$ - orgânico & 2507 & 995 & 1028 & 1042 & 933 & 925 \\
$P$ - total & 907 & & & & & \\
\hline
\end{tabular}


Tabela A-9. Formas de fósforo em ppm $P$, no tratamento 6 (Latossol + vi nhaça + fosfato solūvel) nos diferentes tempos

\begin{tabular}{lcccccc}
\hline $\begin{array}{c}\text { Formas de } \\
\text { fósforo }\end{array}$ & 30 & 60 & 91 & 122 & 151 & 183 \\
\cline { 2 - 7 } & $<1$ & $<1$ & $<1$ & $<1$ & - & $<1$ \\
\hline - solūvel & 24 & 33 & 16 & 29 & - & 14 \\
$P-$ aluminnio & 232 & 159 & 196 & 205 & - & 197 \\
$P$ - ferro & 37 & 42 & 71 & 61 & - & 53 \\
$P$ - cāicio & 280 & 370 & 250 & 267 & 287 & 287 \\
$P$ - orgânico & 1065 & 1100 & 1115 & 1130 & 1171 & 956 \\
$P$ - total & & & & & & \\
\hline
\end{tabular}


Tabela A-10. Formas de fósforo em ppm de P, no tratamento 8 (Latossol + vinhaça + fosfato insolūvel) nos diferentes tempos

\begin{tabular}{lcccccc}
\hline $\begin{array}{c}\text { Formas de } \\
\text { fósforo }\end{array}$ & 30 & 60 & 91 & 122 & 151 & 183 \\
\cline { 2 - 7 } & $<1$ & $<1$ & $<1$ & $<1$ & - & $<1$ \\
\hline$P-$ solüvel & 11 & 11 & 8 & 6 & - & 2 \\
$P-$ aluminio & 117 & 100 & 118 & 123 & - & 111 \\
$P-$ ferro & 139 & 128 & 169 & 159 & - & 141 \\
$P-$ cãicio & 332 & 367 & 220 & 262 & 275 & 308 \\
$P$ - orgânico & 1121 & 1028 & 1094 & 1161 & 1060 & 1071 \\
$P$ - total & 1106 & & & & \\
\hline
\end{tabular}


Tabela A-11. Formas de fósforo em ppm de P, no tratamento 10 (Latossol + fosfato solūvel) nos diferentes tempos

\begin{tabular}{lcccccc}
\hline $\begin{array}{l}\text { Formas de } \\
\text { fósforo }\end{array}$ & 30 & 60 & 91 & 122 & 151 & 183 \\
\cline { 2 - 7 } & $<1$ & $<1$ & $<1$ & $<1$ & - & $<1$ \\
$P$ - solūvel & 35 & 26 & 30 & 54 & - & 40 \\
$P$ - alumīnio & 189 & 166 & 161 & 183 & - & 149 \\
$P$ - ferro & 34 & 33 & 61 & 54 & - & 36 \\
$P$ - cālcio & 335 & 379 & 300 & 288 & 314 & 316 \\
$P$ - orgânico & 1140 & 1109 & 1115 & 1140 & 1115 & 925 \\
$P$ - total & & & & & & \\
\hline
\end{tabular}


Tabela A-12. Formas de fösforo em ppm $P$ no tratamento 12 (Latossol + fosfato insolūvel), nos diversos tempos

\begin{tabular}{|c|c|c|c|c|c|c|}
\hline \multirow{2}{*}{$\begin{array}{l}\text { Formas de } \\
\text { fósforo }\end{array}$} & \multicolumn{6}{|c|}{ Tempo (dias } \\
\hline & 30 & 60 & 91 & 122 & 151 & 183 \\
\hline P - solūvel & $<1$ & $<1$ & $<1$ & $<1$ & - & $<1$ \\
\hline$P$ - aluminio & 10 & 10 & 5 & 44 & - & 14 \\
\hline$P$ - ferro & 144 & 99 & 124 & 99 & - & 119 \\
\hline P - cālcio & 103 & 64 & 118 & 107 & - & 94 \\
\hline$P$ - orgânico & 401 & 437 & 292 & 291 & 321 & 340 \\
\hline$P$ - total & 1115 & 1082 & 1042 & 1109 & 1130 & 973 \\
\hline
\end{tabular}

